\title{
TÜRKIYY'DE GECEKONDU ÖNLEME, TASFIYE VE ISLAH BÖLGELERI
}

\author{
Prevention, Clearance and Improvement Zones \\ for Squatters in Turkey
}

Onur KAPLAN

\section{Öz}

Sanayileşmenin hız kazanmasıyla birlikte yeni bir boyut kazanan kentleşme olgusu, günümüzde yayılarak devam etmektedir. Kırsal kesimden büyük kentlere yapılan göçlerin neticesinde kent merkezlerinde nüfus artışı meydana gelmiş ve fakat o yıllarda altyapının yetersiz olması ve yeterli konut politikasının izlenememesi, bazı sorunların doğmasına sebebiyet vermiştir. İmar mevzuatına aykırı, şehircilik ilkeleri ve planlama esaslara uymayan yapıların bu süreçte kullanılır hale gelmesi bu sorunların çözümünü zorlaştırmaktadır. Özellikle, bireylerin kendisine ait olmayan arazilerde ruhsatsız biçimde yapmış olduğu yapıların şehircilik ilkelerine aykırı olması, can ve mal

Dr. Araştırma Görevlisi, İstanbul Bilgi Üniversitesi Hukuk Fakültesi İdare Hukuku Anabilim Dalı, onur.kaplan@bilgi.edu.tr, Orcid ID: 0000-00031252-6352.

Makale Gönderim Tarihi/Received: 06.10.2020.

Makale Kabul Tarihi/Accepted: 07.12.2020.

Atıf/Citation: Kaplan, Onur. "Türkiye'de Gecekondu Önleme, Tasfiye ve Islah Bölgeleri." ASBÜ Hukuk Fakültesi Dergisi 2, no: 2 (2020): 588-634.

"Bu eser, Creative Commons Attribution-NonCommercial 4.0 International License ile lisanslanmıştır. / This work is licensed under Creative Commons Attribution-NonCommercial 4.0 International License." (9) (9) 
güvenliğini de tehdit etmektedir. Bu nedenle sağlıklı ve dengeli bir çevrenin sağlanabilmesi amaciyla mevcut gecekondu alanlarının revize edilmesi gerekmektedir. Bu kapsamda gecekonduların bundan sonraki dönemde yapılmasının önlenmesi; mevcutların ise gerek münferit gerekse alansal bazda ıslahı ve tasfiyesi hususlarının ele alınması önem taşımaktadır. Bu kapsamda çalışmada, gecekondu önleme, islah ve tasfiye alanlarının tespiti ve bu alanların tespitini müteakip izlenecek uygulama süreci hakkında yargı kararları ışı̆̆ında değerlendirme yapılacaktır.

Anahtar Kelimeler: Kentleşme, Gecekondu, Planlama, Kentsel Altyapı, Tasfiye.

\section{Abstract}

The phenomenon of urbanization, which has gained a new dimension with the acceleration of industrialization, continues to spread today. As a result of the migration from rural areas to big cities, population increase occurred in city centers, but the insufficiency of the infrastructure and the inadequate housing policy in those years caused some problems to arise. The fact that the buildings that are against the zoning legislation and that do not comply with the principles of urbanism and planning are used in this process makes it difficult to solve these problems. Especially, the unlicensed buildings built by individuals on land that do not belong to them are against the principles of urbanism, threatening the safety of life and property. Therefore, existing slum areas should be revised in order to provide a healthy and balanced environment. In this context, preventing the construction of slums in the next period; It is important to address the reclamation and disposal of the existing ones on both individual and spatial basis. In this context, the study will be evaluated in the light of judicial decisions about the determination of the gecekondu prevention, improvement and 
liquidation areas and the implementation process to be followed after the determination of these areas.

Keywords: Urbanization, Squatter, Planning, Urban Infrastructure, Clearance.

\section{Gíriş}

Sanayi Devrimi'nin küresel ölçekte yarattı̆̆ etkilere koşut olarak üretimde farklı yöntemler geliştirilmiş ve sermaye birikimi süreci başlamıştır. ${ }^{1}$ Sanayileşmenin etkisiyle tarım üreticilerinin eski yöntemlerle üretime devam edememesi ve sermaye birikimi yüksek kişilerle baş edememesinin neticesinde ${ }^{2}$, söz konusu kimseler topraklarını satmak zorunda kalmış ve yeni iş imkânları bulabilmek amacıyla kentlere hızlı biçimde göç etmeye başlamışlardır. ${ }^{3}$ 20. yüzyılın ikinci yarısından itibaren kırsal kesimden daha büyük kentlere iş imkanı için gelen kişilerin yarattığ ${ }_{1}$ kentleşme hareketi, kentlerde artan nüfus miktarının başlıca faktörü olmuş ${ }^{4}$ ve buna bağlı olarak devletin oluşan sorunların çözümünde "eylemli bir görev

1 Abdulkadir Aksoy, "Geleneksel Devletten Modern Devlete: Sanayi Devrimi ve Kamu Yönetimi Düşüncesinde Değişim," Uluslararası Politik Araştırmalar Dergisi 2, no. 3 (2016): 34.

2 İlhan Tekeli, Kent, Kentli Hakları, Kentleşme ve Kentsel Dönüşüm (İstanbul: Tarih Vakf1 Yurt Yayınları, 2011), 25.

3 A. Baran Dural ve Sedef Zeyrekli, “Göç Sorunu ve Gecekondulu Nüfusun İktidara Yürüyüşü,” Çă̆daş Yerel Yönetimler Dergisi 15, no. 4 (2006): 5-6.

4 Sabri Çakır, "Türkiye'de Göç, Kentleşme/Gecekondu Sorunu ve Üretilen Politikalar," Süleyman Demirel Üniversitesi Fen Edebiyat Fakültesi Sosyal Bilimler Dergisi, no. 23 (2011): 211; Abdullah Çelik, "Kent Yönetimi Bağlamında Kent Konseyinin İşlevleri Üzerine Bir Değerlendirme," Cumhuriyet Üniversitesi İktisadi ve İdari Bilimler Dergisi 14, no. 2 (2013): 224. 
alma zorunluluğ u" ortaya çıkmıştır. ${ }^{5}$ Ancak o yillarda kentlerin altyapısının yeterli olmaması sebebiyle kentlere göç eden kişilere gerekli imkanlar tam manasıyla sunulamamıştır. ${ }^{6}$ Buna koşut biçimde, büyük kentlerde imkan yetersizliğinin yarattı̆̆ olumsuz barınma koşulları karşısında devlet ve diğer kamu tüzelkişileri artan halk kitlesinin konut ihtiyacıyla ciddi anlamda ilgilenememiştir. ${ }^{7}$

Özellikle kentleşme sürecinin 1950'li yıllardan itibaren dengesiz biçimde ilerlemesi, sosyo-ekonomik farkların büyümesine yol açarken bir yandan fiziksel çevre niteliklerini ve estetik değerlerini olumsuz yönde etkilemiştir. ${ }^{8} \mathrm{Bu}$ dönemde kalıcı çözümler üretilememiş; anlık ve geçici çözümlerle sorunlar halledilmeye çalışılmıştır. ${ }^{9}$ Bu dönemde yapılan gecekondulaşma hareketine de bu doğrultuda tolerans gösterilmiştir. ${ }^{10} \mathrm{Bu}$ toleransın oluşturduğu çarpık kentleşme olgusu, kentleşme hareketinin halen artıyor oluşu ve Türkiye'de

5 Ruşen Keleş, Kentbilim İlkeleri (Ankara: Sevinç Matbaası, 1976), 98-99, aynı yönde; Tuğba Güler ve Nilay Coşgun, "Yapı Üretim Sürecinde Belediyelerin Rolü," Çă̆daş Yerel Yönetimler Dergisi 20, no. 2 (2011): 64-65.

6 Manuel Castells, Kent Sını İktidar, çev. Asuman Türkün (Ankara: Phoenix Yayınları, 2014), 15.

7 Fehmi Yavuz, Ruşen Keleş ve Cevat Geray, Şehircilik Sorunlar-Uygulama ve Politika (Ankara: Sevinç Matbaası, 1973), 573; Ercan Tatlıdil, Kentleşme ve Gecekondu (İzmir: Ege Üniversitesi Edebiyat Fakültesi Yayınları, 1989), 11.

8 Cengiz Giritlioğlu, "İç Göç ve Kentlileşme," Türkiye'de Kentleşme (Ankara: Yeni Yüzyıl Kitaplığı, 1995), 32; Ruşen Keleş, “Türkiye'de Şehirleşme Hareketleri," Ankara Üniversitesi Siyasal Bilgiler Fakültesi Dergisi 25, no. 4 (1970): 49.

9 Metin Heper, "Türkiye' de Gecekondu Politikası Üzerine Bazı Düşünceler," Amme İdaresi Dergisi 12, no. 4 (1979): 55.

10 Tahire Erman, "Formalization by the State, Re-Informalization by the People: A Gecekondu Transformation Housing Estate as Site of Multiple Discrepancies," International Journal of Urban and Regional Research 40, no. 2 (2016): 426. 
konut ihtiyacının varlığı karşısında büyüyen bir problem haline gelmiştir. ${ }^{11}$ Öyle ki, gecekondu yapılarının ("squatters") oluşmasının yanında bunların tasfiye edilememesi; ${ }^{12}$ çözüm noktasında, idari makamları adeta fasit daire içerisine sokmuştur.

Şehircilik, kentleşme olgusuna bağlı olarak insanların bir arada yaşayacakları yerleri, onların yaşam şartlarına en uygun şekilde düzenlenmesini ve planlanmasını içeren bir terimdir. ${ }^{13}$ Esasen, şehircilik ilkeleri bağlamında kent kavramının kamusal bir mekan olmasi14 burada yaşayan bireylerin barınma ve yerleşme haklarının yanında sağlıklı bir çevrede yaşama haklarını da etkilediğinden; idari makamların "içselleştirilen gecekondulaşma sorununa15" karşı kent formunu bozan gecekondu alanlarına yönelik müdahalesi daha da elzem hale gelmiştir. Büyük kentlerde yanlış kentleşmenin doğurduğu olumsuz sonuçların başında gelen gecekondulaşmanın ${ }^{16}$ ortadan kaldırılması ve sağlıklı bir kent formunun oluşturulmasına yönelik yasal düzenlemelere zaman içerisinde hukuk sistemimizde yer verilse de bunların uygulanmasında yaşanan

11 Cevat Geray, "Urbanization in Turkey," Ankara Üniversitesi Siyasal Bilgiler Fakültesi Dergisi 24, no. 4 (1969): 168. Gecekonduların oluşturduğu yapılaşmaların çeşitli büyük şehirlerdeki örnekleri hakkında bkz. William Mangin, "Latin American Squatter Settlements: A Problem and a Solution," Latin American Research Review 2, no. 3 (1967): 65.

12 Sevim Aktaş, "The Urbanisation Issue and the Culture of Gecekondus in Turkey," Oriente Moderno, no. 93 (2013): 177.

13 C. Esad Arseven, Şehircilik (Urbanizm) (İstanbul: Devlet Basımevi, 1937), 4.

14 M. Ali Kılıçbay, Şehirler ve Kentler (Ankara: Gece Yayınları, 1993), 29.

15 P. Pinar Özden, Kentsel Yenileme Yasal Yönetsel Boyut Planlama ve Uygulama (Ankara: İmge Kitabevi, 2016), 261.

16 Çakır, “Türkiye'de Göç, Kentleşme/Gecekondu Sorunu ve Üretilen Politikalar," 211. 
eksiklikler ve imar afları nedeniyle ${ }^{17}$ beklenen hedefe ulaşılamamıştır. Gerçekten doktrinde Gülan'ın vurguladığı üzere, "zannedilenin ve beklenenin aksine, sorunu çözmek için getirildiği düşünülen yaptırım içeren, mahkemelerce hüküm tesisinde kullanilan metinlerin, kimi zaman, aslında sorunun yaşamasına uygun ortamı oluşturan ve gelişimi için zemin teşkil eden hale geldiği görülebilmektedir". ${ }^{18}$

\section{GECEKONDU KAVRAMININ TANIMLANMASI VE TANIMLAMANIN SONUÇLARI}

Gecekondu kavramı, kentleşme sürecinin ortaya çıkardığı bir sorun olarak geçmişten günümüze değin incelenmiş ve tartışılmış bir konudur. ${ }^{19}$ Mekan olarak, "kentsel imara açılmamış, altyapısı gerçekleştirilmemiş, başka şahıslara ve kamuya ait araziler üzerinde" uygun teknolojik koşullara ve planlama esaslarına uygun yapılmayan yapıların gecekondu niteliğinde olduğundan bahsedilebilir. ${ }^{20}$ Türk hukuk sisteminde gecekondu kavramıla ilgili olarak çıarılan temel yasal düzenleme 775 sayılı Gecekondu Kanunu'dur ${ }^{21} .775$ sayılı Kanun md. 2 kapsamında gecekondu kavramının geniş tanımına yer verildiği

17 P. Pınar Giritlioğlu ve Kardelen Özden, "Kentsel Adalet Ekseninde İmar Afları: İmar Barışı Üzerine Bir Değerlendirme," Prof. Dr. Necla Giritlioğlu'na Armağan (İstanbul: On İki Levha Yayıncılık, 2020): 266ff.; Feral Eke, “Gecekondu Alanlarının Değerlendirilmesine İlişkin Çözümler," Süleyman Demirel Üniversitesi İktisadi ve İdari Bilimler Fakültesi Dergisi 5, no. 1 (2000): 48-49. Ayrıca bkz. Halil Kalabalık, İmar Barışı Başvuru Süreci ve Sonuçları (Ankara: Seçkin Yayıncılık, 2018), 231ff.

18 Aydın Gülan, "Şehircilik Sorunlarının Ağırlaşmasında Hukukun Rolü Hakkında Düşünceler," İstanbul Üniversitesi Sosyoloji Dergisi 3, no. 22 (2011): 296.

19 Mustafa Kaya, "Gecekondu Sorunu ve Gecekondu Kanunu," Türkiye Barolar Birliği Dergisi, no. 1989/6 (1989): 863.

20 Tatlıdil, Kentleşme ve Gecekondu, 15.

21 RG. 30.07.1966, S. 12362. 
görülmektedir; buna göre gecekondu kavramı, “imar ve yapı işlerini düzenleyen mevzuata ve genel hükümlere bağhl kalınmaksızın, kendisine ait olmayan arazi veya arsalar üzerinde, sahibinin rizası alınmadan yapılan izinsiz yapılar" olarak tanımlanmıştır. Başka bir deyişle gecekondu, mevzuata aykırı, arsa sahibinin rızasının bulunmadığı, başkasına ait arsa veya arazi üzerine yapılan ruhsatsız yapılardır.22 Maddenin lafzından yola çıkılacak olursa, genel anlamda şehircilik ilkeleri ve planlama esasları göz ardı edilerek, kendisine ait olmayan arsa ve arazi üzerine sahibinin rızası olmaksızın (toprak iyesinin istenç ve bilgisi dışında onamsız olarak yapılan) ${ }^{23}$ inşa edilen bu yapılar, gecekondu statüsündedir. Danıştay'ın vermiş olduğu bir kararda belirtildiği şekilde, "775 Sayılı Kanunun 2. maddesinde, bu Kanunda sözü geçen "Gecekondu" deyimi ile imar ve yapı işlerini düzenleyen mevzuata ve genel hükümlere bağlı kalınmaksızın, kendisine ait olmayan arazi veya arsalar üzerinde, sahibinin rızası alımmadan izinsiz yapılan yapıların kastedildiği hüküm altına alınmıştır. Madde düzenlemesi böyle olunca, 775 Sayıl Kanunun 18. maddesinin uygulanabilmesi için mülkiyeti ihtilafsız olan arazi veya arsa üzerinde, sahibinin rızası alınmadan yapılmış izinsiz yapının bulunması gerekmektedir". ${ }^{24}$ Yapının gecekondu statüsünde olması neticesinde bu statüye bağlanan bazı sonuçlar da meydana gelmektedir. Örneğin, yapının gecekondu niteliğinde olduğunun tespiti neticesinde y1kım uygulaması gerçekleştirilebilmektedir. ${ }^{25}$ Yahut bir yapının

22 Cevat Geray, "Gecekondu Sorununa Toplu Bir Bakış," Amme İdaresi Dergisi 1, no. 2 (1968): 12.

23 Ruşen Keleş, Kentbilim Terimleri Sözlü̆̆̈̈ (Ankara: İmge Kitabevi, 1998), 53.

24 Dan. 6. D. E.2010/7816, K.2010/11274, T.14.12.2010, Kazancı İçtihat Bilgi Bankası.

25 Yapının, 775 sayılı Gecekondu Kanunu kapsamında idari makamlar tarafından gecekondu olduğunun tespit edilmesi neticesinde, kamu alanında kalan bu yapıların yıkımının gerektiğine dair bkz. Dan. 6. D. E.2019/8377, K.2020/1718, T.13.02.2020, Kazancı İçtihat Bilgi Bankası. 
gecekondu niteliğinde olduğunun tespit edilmesi neticesinde gecekondu sahibinin belirli pozitif yükümlülükleri yerine yetirmesi gündeme gelebilmektedir. ${ }^{26}$

Bunun yanında, bir yapinın yetkili idari makamlar tarafından idari işlemle "gecekondu" statüsünde olduğunun tespit edilmesi, o yapının hukuki statüsünü değiştirmekle beraber bulunduğu alanın da hukuki statüsünü etkileyebilmektedir. Özellikle, gecekondu bölgeleri olarak ifade edilebilecek alanlarda, ${ }^{27}$ "gecekondu" olduğu tespit edilen yapiların $^{28}$ yoğunluğu hususu göze çarpmaktadır. Örneğin, Danıştay tarafından verilmiş olan bir kararda bu hususa değinilerek; "bölgede, să̆lıksız, çarpık yapılaşma ve imara aykırı gecekondu niteliğindeki yapıların yoğun olarak bulunması nedeniyle

26775 sayılı Kanun md. 17: "Belediye stmırlar ve varsa mücavir sahalar içindeki bütün gecekondularm ve ayraca $16 \mathrm{nct}$ madde gereğince tesbit edilen bölge ve sahalar içinde bulunan bütün yapıların sahipleri ve her ne şekilde olursa olsun bu yapılarda oturan veya bunları işyeri olarak kullananlar, Toplu Konut İdaresi Başkanlı̆̆ınca hazırlanacakörneğe uygun bir beyannameyi ilan tarihinden itibaren 3 ay içerisinde yapının bulunduğ u yer belediyesine makbuz karşılığında vermek zorundadirlar".

27775 sayılı Kanun md. 16/6: “Belediye sınırları ve varsa mücavir sahalar dışındaki gecekondu bölgelerinde bu madde gereğince yapılması gereken işlemler, Toplu Konut İdaresi Başkanlığınca yürütülür". 775 sayılı Kanun md. 16/7 "Gerek gecekondu bölgelerinin gerekse ıslah veya tasfiye edilecek gecekondularm tesbit şekli ve esasları, mahalli özellikler ve teknik imkanlar da gözönünde tutularak, Toplu Konut İdaresi Başkanlığınca tayin olunur".

28 Belirtmek gerekirse, 775 sayılı Kanun' da da gecekonduların "yapı" olarak nitelendirilmesi; konutların dişında başkaca unsurların da gecekondu olarak değerlendirilmesini sağlamaktadır. Kaya, "Gecekondu Sorunu ve Gecekondu Kanunu," 871. Yapı kavramının tanımı hakkında ayrıca bkz. Taner Ayanoğlu, Yapı Hukukunun Genel Esasları (İstanbul: Vedat Kitapçılık, 2014), 3; Ömer Köroğlu, İmar Hukukunda Yapı Kavramı ve Temel Yapı Belgeleri (İstanbul: On İki Levha Yayıncılık, 2017): 5; Hüseyin Bilgin, “7153 ve 7181 Sayılı Kanunlarla İmar Kanununda Yapılan Değişiklikler Üzerine Bir İnceleme," Anadolu Üniversitesi Hukuk Fakültesi Dergisi 6, no. 2 (2020): 348. 
16/07/2009 tarih ve 3412 Sayılı Toplu Konut İdaresi Başkanlı̆̆g oluru ile anılan taşınmazın bulunduğu bölge(nin) (...) gecekondu önleme bölgesi olarak belirlen(diği)"29 ifade edilmiştir. İlgili bölgenin mevcut durumu saptanırken ise; 775 sayılı Kanun md. 16'ya göre, "gecekondu ıslah ve tasfiye bölgeleri ve bunlartn sinırları, belediyelerce bu kanunun yayımı tarihinden itibaren en geç 6 ay içinde, her türlü imkan ve araçtan faydalanilarak tesbit olunur". Bu husus, özellikle bu yapıların hukuka aykırı biçimde yapıldığı dikkate alındığında "risk" unsurunun önceden belirlenmesi bakımından önem taşımaktadır. ${ }^{30}$ Zira kentsel mekanlarda çevre, fen ve sağlık koşullarına uygun biçimde yapılmayan yapılar, ${ }^{31}$ sonrasinda kent altyapisinı olumsuz etkilemekte; bunun yanında olası afet riskine karşı can ve mal güvenliğini tehdit etmektedir. Bu anlamda bunun en somut örneğini "gecekondular" oluşturmaktadır. ${ }^{32}$

Doktrinde Giritlioğlu/Özden'in ifade ettiği üzere, gecekondu yapan bireyler yönünden iki bakış açısı mevcut olup;

29 Dan. İDDGK. E.2019/3342, K.2020/148, T.30.01.2020, Kazancı İçtihat Bilgi Bankası.

30 Belirsizlikten ileri gelen bir kavram olarak risk; etkinliklerin, planlamaların ve tasarımların kendisinde var olan kaçınılmaz bir potansiyel unsurunu ifade etmektedir. Riskin nedenleri yanında sonuçları da bulunduğu göz önüne alındığında; bu kavramı yan etkileriyle birlikte değerlendirmek gerekecektir. Altay Gündüz, "Gerçek Yapısal Riskin Tahmin Edilmesi Üzerine," Türkiye İnşaat Mühendisliği 13. Teknik Kongresi Bildiriler Kitabı (Ankara: 1995) 282; Gülcan Azimli Çilingir ve İlke Örçen Güler, "Afet Politikalarında Risk Unsuru ve Afet Mevzuatında Risk Yönetimi," Uluslararası Yönetim Akademisi Dergisi 3, no. 1 (2020): 159. Ayrıca bkz. Özlem Güzey, "The Last Round in Restructuring the City: Urban Regeneration becomes a State Policy of Disaster Prevention in Turkey," Cities 50 (2016): 52.

31 Aydin Aybay, "A Survey of the Gecekondu Act, 1966, from the Standpoint of Effective Land Use," Annales de la Faculté de Droit d'Istanbul 23, no. 39 (1975): 203.

32 Aybay, "A Survey of the Gecekondu Act," 203-204. 
"ilki, gecekonducuya, devletin yerine getirmediği barımma hakkın temin etmek üzere kendi çözümünü geliştiren topluluklar olarak yaklaşan bakış açısı, diğeri ise, gecekonducuyu, kentte yaşamanın bedellerine katlanmadan kentsel ranttan ve firsatlardan payını almış, hızla ekonomik sınıf atlamış ve adil olmayan bir yolla, kentsel hayatın parçası haline gelmiş topluluklar olarak kabul eden bakış açısıdır". ${ }^{33}$ Dolayısıyla gecekondu konusu ele alınırken AY md. 57 kapsamında bir sosyal hak olan konut hakkının yanında yaşam hakk1 $^{34}$ (AY md. 17) ve yerleşme hürriyetinin ${ }^{35}$ (AY md. 23) birey yönünden değerlendirilmesi; bunun yanında sağlıklı ve dengeli bir çevrede yaşama hakkının ${ }^{36}$ (AY md. 56) kullanılabildiği bir düzenin yaratılması maksadiyla "müdahale" unsurunun ne şekilde gerçekleşebileceğinin AY md. 13 kapsamında ${ }^{37}$ irdelenmesi gerekmektedir. Gecekondu olarak ifade edilen

33 Giritlioğlu ve Özden, “Kentsel Adalet Ekseninde İmar Afları,” 275.

34 AY md. 17/1: "Herkes, yaşama, maddî ve manevî varlığımı koruma ve geliştirme hakkına sahiptir".

35 AY md. 23/1: "Herkes, yerleşme ve seyahat hürriyetine sahiptir"; AY md. 23/2 "Yerleşme hürriyeti, suç işlenmesini önlemek, sosyal ve ekonomik gelişmeyi sağlamak, să̆lıklı ve düzenli kentleşmeyi gerçekleştirmek ve kamu mallarını korumak; Seyahat hürriyeti, suç soruşturma ve kovuşturması sebebiyle ve suç işlenmesini önlemek; Amaçlarıyla kanunla sınırlanabilir".

36 AY md. 56: "Herkes, sağlıklı ve dengeli bir çevrede yaşama hakkına sahiptir. Çevreyi geliştirmek, çevre sağhı̆̆ını korumak ve çevre kirlenmesini önlemek Devletin ve vatandaşların ödevidir. Devlet, herkesin hayatını, beden ve ruh să̆ğh̆̆ içinde sürdürmesini sağlamak; insan ve madde gücünde tasarruf ve verimi artırarak, işbirliğini gerçekleştirmek amacıyla sağlık kuruluşlarını tek elden planlayıp hizmet vermesini düzenler. Devlet, bu görevini kamu ve özel kesimlerdeki sağlık ve sosyal kurumlarından yararlanarak, onları denetleyerek yerine getirir. Sağllk hizmetlerinin yaygın bir şekilde yerine getirilmesi için kanunla genel să̆lık sigortası kurulabilir".

37 AY md. 13: "Temel hak ve hürriyetler, özlerine dokunulmaksızın yalnızca Anayasanın ilgili maddelerinde belirtilen sebeplere bağlı olarak ve ancak kanunla sinırlanabilir. Bu sinırlamalar, Anayasanın sözüne ve ruhuna, demokratik toplum düzeninin ve lâik Cumhuriyetin gereklerine ve ölçülülük ilkesine aykırı olamaz". 
yapıların artan kentleşme olgusu karşısında barınma ihtiyacını bir ölçüde karşıladığı tezi de göz önüne alındığında; müdahalenin yalnızca yapının yıkılması veya ortadan kaldırılmasına yönelik değil ve fakat bütüncül biçimde nüfus dağılımlarını da içerir biçimde yapılması daha anlamlı olmaktadır. ${ }^{38} \mathrm{Bu}$ anlamda Oder'in belirttiği şekilde, temel hak ve hürriyetlerin "korunması" ve "sağlanması" düzlemi ile idari makamların temel hak ve hürriyetlere "müdahalesi" düzlemi arasında bağıntı kurulması icap eder. ${ }^{39} 775$ sayılı Kanun'un hedeflerine bakıldığında da mevcut yapıların oluşturduğu düzensiz kent dokusunun yenilenmesi ve ıslahı ile yeniden bu yapıların yapılmasının önüne geçilmesi unsurlarının ön planda olduğu görülmektedir. ${ }^{40}$ İşte, gecekondu tasfiye, sslah ve önleme bölgeleri olarak somutlaşan bu hedefler bakımından "tespit ve ilan aşamasının", sonrasında "uygulama aşamasının" açıklanması gerekmektedir.

\section{GECEKONDU ISLAH, TAHLIYE VE ÖNLEME BÖLGELERI ÇERÇEVESINDE UYGULAMA}

Konut ihtiyacının karşılanması hususu, 1948 tarihli BM İnsan Hakları Evrensel Bildirgesi'nde kendine yer bulan;41

38 Cevat Geray, "Mesken Meselesi ve Dördüncü İskân ve Şehircilik Haftası," Ankara Üniversitesi Siyasal Bilgiler Fakültesi Dergisi 15, no. 3 (1960): 127.

39 Burak Oder, “Regülasyon Kavramı Üzerine Bir Deneme," Prof. Dr. A. Ülkü Azrak 75. Yaş Armağanı (İstanbul: Çizgi Basım Yayın, 2008), 247.

40 Kaya, “Gecekondu Sorunu ve Gecekondu Kanunu," 871.

411948 tarihli İnsan Hakları Evrensel Bildirgesi md. 25/1'e göre "Her şahsin gerek kendisi gerekse ailesi için, yiyecek, giyim, mesken, tıbbi bakını, gerekli sosyal hizmetler dâhil olmak üzere sağhğ̆ ve refahını temin edecek uygun bir hayat seviyesine ve işsizlik, hastalık, sakatlık, dulluk, ihtiyarlık veya geçim imkânlarından iradesi dışında mahrum bırakacak diğer hallerde güvenliğe hakkı vardır". Bkz. RG. 27.05.1949, S. 7217. Ayrıca bkz. Günay Gönüllü, “Çevresel-Kentsel Hakların 
bununla birlikte sosyal haklarda yaşanan gelişmelere bağlı olarak $^{42}$ anayasalarda düzenlenen bir konu olarak karşımıza çıkmaktadır. Nitekim 1961 Anayasası md. 49/2 193 Anayasası ("AY") md. 57'de Devletin konut ihtiyacını karşılayıcı tedbirleri alması gerektiği hususu düzenlenmiştir. AY md. 57'ye göre, "Devlet, şehirlerin özelliklerini ve çevre şartların gözeten bir planlama çerçevesinde, konut ihtiyacını karşılayacak tedbirleri alır, ayrıca toplu konut teşebbüslerini destekler". Dolayısıyla devletin konut ihtiyacının karşılanmasına dair önlemlerin alınmasının yanında kentlerin özelliklerini ve sağlıklı çevrenin oluşturulmasını gerçekleştirme yükümlülüğü bulunmaktadır. ${ }^{44}$ $\mathrm{Bu}$ kapsamda devlete toplu konut girişimlerini desteklemesi yönünde pozitif yükümlülük getirilmesi, konut hakkının sağlık hakkının parçası olmaktan çıkarılması olumlu gelişmelerdendir. ${ }^{45}$ Bununla beraber buradaki konut hakkının doktrinde Onar'ın belirttiği şekliyle "sübjektif kamu hakkı" olarak değerlendirilmesi, yani "idarenin vecibesinin ifasmı istiyen kimsenin şahsî bir menfaatinin mevcudiyeti" 46 söz konusu değildir. Örücü'nün de ifade ettiği üzere "nerede bir sosyal hak varsa orada

Gelişimi: Dünyada ve Türkiye'de Kentsel Haklar," İnsan Hakları Yıllığı Dergisi 32 (2014): 9.

42 Nurten İnce, İ. Bakır Kanlı ve B. Hamza Eryiğit, “İnsan Hakkı Olarak Konut Hakkı," Uluslararası Politik Araştırmalar Dergisi 3, no. 2 (2017): 22.

431961 Anayasası md. 49/2: "Devlet, yoksul veya dar gelirli ailelerin să̆lık şartlarına uygun konut ihtiyaçlarını karşılayıcı tedbirleri alır".

44 Erdal Abdulhakimoğulları ve Fatmagül Kale, "Türk Anayasalarında ve Karşılaştırmalı Hukukta Konut Hakkı," Türkiye Adalet Akademisi Dergisi 4, no. 15 (2013): 20.

45 Ruşen Keleş, 100 Soruda Türkiye'de Kentleşme, Konut ve Gecekondu (İstanbul: Cem Yayınevi, 2015): 308.

46 S. Sami Onar, İdare Hukukunun Umumî Esasları Cilt-I (İstanbul: Hak Kitabevi, 1966), 501. 
kamu hizmetinin kurulması zorunluluğ ${ }^{\prime \prime 4}$ ortaya çıksa da buradaki hakkın içeriğinin devletin planlama faaliyetinde bulunarak konut ihtiyacını karşılayacak biçimde konut üretimi yapması gerektiği ve toplu konut teşebbüslerini desteklemesi noktasında ön plana çıtı̆̆ı görülmektedir. Başka bir deyişle, konut hakkının bir sosyal hak olmasının; (i). devletin toplu konut teşebbüslerini desteklemesi ve varsa konut ihtiyacını giderici önlemler alması dişında sübjektif kamu hakkı oluşturmayacağı, (ii). kamu hizmeti faaliyeti yönünden daha ziyade planlama ve sağlıklı bir şehirleşmenin sağlanması konusunda belireceği ifade edilebilir. Ne var ki, artan şehirleşme olgusuna rağmen yeterli konut politikasının izlenememesi sonucunda konut arzının doğurduğu konut ihtiyacı uygun biçimde sağlanamamıştır. ${ }^{48} \mathrm{Bu}$ nedenle kentleşmenin artmasına koşut olarak -kent ve birey arasındaki etkileşim de göz önüne alındığında ${ }^{49}$ - kentlerin şehircilik ve planlama ilkelerine göre yeniden düzenlenmesi ihtiyac1 kapsaminda gecekonduların da yeniden yapılandırılması gereği doğmuştur. Kentsel altyapı ve hizmetlerin zamanla gelişmesiyle doğru orantılı olarak gecekondulaşma olgusunda azalma gözlenmişse de ${ }^{50}$ günümüzde halen gecekondulaşmanın var olduğu bölgeler mevcuttur. Öte yandan, çıarılan imar affı yasaları ve gecekonduların 775 sayılı Kanun'la yasal statüye kavuşturulması ve kentin bir parçası olduğunun kabul

47 Esin Örücü, Sosyal Refah Devletinde Bir Sosyal Kamu Hizmeti Konut (İstanbul: İstanbul Üniversitesi Hukuk Fakültesi Yayınları, 1972), 24.

48 Örücü, Sosyal Refah Devletinde Bir Sosyal Kamu Hizmeti Konut, 50.

49 Henri Labort, İnsan ve Kent, çev. Bertan Onaran (İstanbul: Payel Yayınları, 1990), 24; R. Cengiz Derdiman, "Kentleşmenin Suça Etkisi ve Kentlilerin Suçla Mücadelesinin Sosyal ve Hukuki Boyutları," Çă̆daş Yerel Yönetimler Dergisi 19, no. 3 (2010): 51.

50 T.C. Kalkınma Bakanlığı, Onuncu Kalkınma Planı (2014-2018), RG. 06.07.2013, S. 28699 (Mükerrer). 
edilmesi, ${ }^{51}$ bu yapıların ticarileşmesine yol açmıştır. ${ }^{52} \mathrm{Bu}$ çerçevede çıkarılan yasal düzenlemelerden maksat, mevcut gecekonduların yarattığı olumsuz etkilerin ortadan kaldırılması ve olası gecekondulaşma hareketinin önüne geçilmesidir. ${ }^{53}$

Gecekondulaşmanın kentlerde yarattığı olumsuz etkilerin ortadan kaldırılmasına yönelik uygulamaların başında kentsel dönüşüm uygulamaları gelmekte olup, bu kapsamda belediyelere ve Toplu Konut İdaresi Başkanlığına (TOKİ) birtakım pozitif yükümlülükler getirildiği görülmektedir. ${ }^{54}$ Kent mekânlarında hukuka uygun olmayan biçimde yapılmış yapıların yoğun olduğu ve kent altyapı olanaklarının gelişmediği bölgelerde, söz konusu kent dokusunun ıslahının sağlanabilmesi çerçevesinde geliştirilen çözümlerde alansal uygulamalar öngörülmektedir. ${ }^{55}$ Gecekondu konusu da sadece

51 Erman Aksoy ve Özlem Güzey Kocataş, “Gecekondu Alanlarında Uygulanan Kentsel Dönüşüm Projelerinin Meşruiyet Zemini Olarak Yoksulluk ve Suç," Karadeniz Teknik Üniversitesi Sosyal Bilimler Enstitüsü Sosyal Bilimler Dergisi 7, no. 14 (2017): 278.

52 Çiğdem Aksu Çam ve Ezgi Uygur, "Yıkım-Tapu-Dönüşüm Tartışmalarıyla Türkiye'de Enformel Konut Üretimi: Adana Örneği," Aksaray Üniversitesi İktisadi ve İdari Bilimler Fakültesi Dergisi 10, no. 4 (2018): 2.

53 İsmail Ceritli, “Kentsel Planlamanın İlkeleri ve Türkiye'de Gecekondu Sorunu," Öneri Dergisi 2, no. 10 (1998): 55.

54 Fatma N. Genç, “Türkiye' de Kentsel Dönüşüm: Mevzuat ve Uygulamaların Genel Görünümü," Yönetim ve Ekonomi Dergisi 15, no. 1 (2008): 116.

555393 sayılı Belediye Kanun md. 73/1: "Belediye, belediye meclisi kararryla; konut alanlar, sanayi alanlar, ticaret alanlarl, teknoloji parklarl, kamu hizmeti alanları, rekreasyon alanları ve her türlü sosyal donatı alanları oluşturmak, eskiyen kent kısımların yeniden inşa ve restore etmek, kentin tarihi ve kültürel dokusunu korumak veya deprem riskine karşı tedbirler almak amacıyla kentsel dönüşüm ve gelişim projeleri uygulayabilir..."; 5366 sayılı Yıpranan Tarihi ve Kültürel Taşınmaz Varlıkların Yenilenerek Korunması ve Yaşatılarak Kullanılması Hakkında Kanun md. 1/2: "Bu Kanun, yukarıda belirtilen amaçlar doğrultusunda oluşturulacak olan yenileme alanlarmın tespitine, teknik altyapr ve yapısal standartlarının belirlenmesine, projelerinin oluşturulmasına, uygulama, 
münferit bir sorun olarak değil ve fakat ilgili bölgeyi ilgilendiren bir grup sorunu olarak ele alınırsa, o kent mekânının planlanması ve konutların yapılacağı alanlarda altyapının sağlanması daha efektif biçimde gerçekleştirilebilecektir. ${ }^{56} \mathrm{Bu}$ bağlamda gecekondulaşmanın önlenmesi maksadıyla 775 sayılı Kanun çerçevesinde gecekondu tasfiye, islah ve önleme bölgelerinin idari makamlar tarafından tespit edilmesi, alansal bazda uygulamanın ön planda olduğunu göstermektedir. Başka bir deyişle, gecekonduların yarattığı olumsuz sonuçların giderilebilmesi ve yeni sorunların önlenmesi için; gecekonduların yer aldığı bölgelerin 1slahı ve belirlenen yerlerde hukuka uygun konutlar yapılmasının sağlanması hedef tutulmuştur. ${ }^{57} \mathrm{Bu}$ kapsamda söz konusu alanların ilan edilmesi ve alansal bazda uygulama dahilinde gecekondulaşmanın olumsuz sonuçlarının bertaraf edilmesi ve kent mekanına daha iyi bir görünüm kazandırarak can ve mal güvenliğinin sağlanmasına yönelik olarak gecekondu önleme, islah ve tahliye bölgesi kapsamında uygulamalar geliştirilmektedir. ${ }^{58}$

\section{A. İlan Aşaması}

Artan gecekondulaşma olgusunun önlenmesi ve mevcut gecekondu bölgelerinin sslah ve tasfiyesi amacıyla yetkili idari

örgütlenme, yönetim, denetim, katılım ve kullanımına ilişkin usûl ve esasları kapsar"; 5104 sayılı Kuzey Ankara Girişi Kentsel Dönüşüm Kanunu md. 1: "Bu Kanunun amacl, kuzey Ankara girişi ve çevresini kapsayan alanlarda kentsel dönüşüm projesi çerçevesinde fiziksel durumun ve çevre görüntüsünün geliştirilmesi, güzelleştirilmesi ve daha sağhlklı bir yerleşim düzeni sağlanması ile kentsel yaşam düzeyinin yükseltilmesidir".

56 Heper, “Türkiye' de Gecekondu Politikası Üzerine Bazı Düşünceler," 59.

57 Serdar Sağlam, “1923-1950 Yılları Arasında Türkiye'de Kent ve Kentleşme Olgusu," Sosyoloji Konferanslarl, no. 53 (2016): 269.

58 Bkz. Gül Üstün, Kentsel Dönüşüm Hukuku (İstanbul: On İki Levha Yayıncılık, 2014), 31-32. 
makamlar tarafından alansal bazda uygulama yapılmaktadır. Bu kapsamda gecekondu sslah ve tasfiye bölgelerinin tespit edilerek, plansız faaliyetler dışlanarak bu alanlarda şehircilik ve planlama ilkelerine uygun olarak yapılaşmaya gidilmesi hedeflenmektedir. ${ }^{59} \mathrm{Bu}$ sayede bölgenin niteliğine ilişkin maddi olguların saptanmasından sonra (=bölgedeki gereksinimler saptanmış olacă̆ından), kentsel planlamanın daha iyi sağlanması ve altyapı sunumlarının gereği gibi gerçekleştirilmesi sağlanabilecektir. ${ }^{60} \mathrm{Bu}$ hususta Türk hukuk sisteminde var olan eklektik yapı bir kez daha somutlaşarak,, ${ }^{61}$ bir anlamda 1960'l 1 yıllara kadar izlenen gecekondu politikasında bir değişim yaşanmış ve gecekondu yapılarına müdahalenin önü çıkarılan yasal düzenlemelerle açılmaya başlanmıştır. ${ }^{62} \mathrm{Bu}$ doğrultuda gecekondu alanlarına yönelik müdahalenin planlı yapılması maksadıyla çıkarılan 775 sayılı Kanun uyarınca gecekondu ıslah, tasfiye ve önleme bölgeleri ile ilgili ilk aşama tespit ve ilan aşamasıdır. ${ }^{63}$ Gecekondu ıslah ve tasfiye bölgesi ilanı yetkili idare tarafından tesis edilecek idari işlem sonucu gerçekleşmektedir. Bu nedenle söz konusu bölgelerin tespiti

59 Şebnem Eroğlu, "Extending the Resource-Based Approach to Livelihoods: An Urban Application to Turkish Gecekondu Households," International Journal of Urban and Regional Research 37, no. 2 (2013): 782.

60 Kamutay Türkoğlu and A. Saffet Atik, “Bütünsel Kentsel Planlama ve Altyapı Projelendirmesi Kent Yönetiminin ve Kentsel Gelişmenin Ayrılamaz İkilisidir," I. Ulusal Kentsel Altyapı Sempozyumu Bildiriler Kitabı (G. Antep: TMMOB İnşaat Mühendisleri Odası Yayınları, 1997), 5.

61 Esin Örücü, "A Synthetic and Hyphenated Legal System: The Turkish Experience," Journal of Comparative Law 1, no. 2 (2006): 261.

62 Asuman Türkün, Şükrü Aslan ve Besime Şen, “1923-1980 Döneminde Kentsel Politikalar ve İstanbul'da Sosyo-Mekânsal Dönüşüm," Mülk, Mahal, İnsan İstanbul'da Kentsel Dönüşüm, der. Asuman Türkün (İstanbul: İstanbul Bilgi Üniversitesi Yayınları, 2014), 71.

63 Türkün, Aslan ve Şen, "1923-1980 Döneminde Kentsel Politikalar ve İstanbul'da Sosyo-Mekânsal Dönüşüm," 72. 
maksadıyla yetkili idari makamin karar alması elzemdir. ${ }^{64}$ Yetkili idari makamlar tarafından tespit edilen gecekondu ıslah, tasfiye ve önleme bölgeleri, tespite yönelik iradenin hukuk düzeninde sonuç doğurması neticesinde "idari işlem" olarak nitelendirilmekte ve bu işlem ilgili alanın hukuki statüsü üzerinde etkisini göstermektedir. Bu doğrultuda söz konusu bölgelerin tespit edici idari işlemlerle belirlenmesi neticesinde o bölgede yaşayan gecekondu sahiplerinin AY md. 35 ve md. 56 kapsamında temek hak ve hürriyetleri etkilendiğinden; bu işlemlerin idari yargıda dava konusu edilebilmesi mümkündür. ${ }^{65}$ Başka bir deyişle, gecekondu bölgelerinin tespiti işleminin hazırlık süreci tamamlanan ${ }^{66}$ "kesin ve yürütülmesi gerekli bir idari işlem" niteliğinde ${ }^{67}$ olduğundan bahsedilebilir.

Gecekonduların münferit olarak tespiti ve gecekondu islah ve tasfiye alanlarının belirlenmesinde yetkili idari makam, belediyelerdir. Mahalli müşterek ihtiyaçların karşılanmasının en iyi mahalli idareler eliyle gerçekleşeceği düşüncesiyle, ${ }^{68} 775$

64 Belirtmek gerekirse, yapının gecekondu niteliğinde olduğunun tespiti yahut bölgenin gecekondu önleme, 1slah veya tasfiye bölgesi olarak saptanması; ilgili nesnenin hukuki statüsünü değiştirmekte olup söz konusu maddi olgu veya hukuki durumların tespitinin bu anlamda yetkili idari makam tarafından yapılması zaruriyet arz etmektedir. Başka bir deyişle idari makam tarafından saptanan olgular maddi dünyada öncesinde mevcut olsa da bunun sarih bir irade beyanıla tespit edilerek hukuk düzeninde etki üretmesi icap etmektedir. Bkz. Onur Karahanoğulları, İdarenin Hukukla Kavranması: Yasallık ve İdari İşlemler (Ankara: Turhan Kitabevi, 2018), 300.

65 Dan. 10. D. E.1997/2393, K.2000/935, T.21.02.2000, Kazanc1 İçtihat Bilgi Bankası.

66 Dan. $15 . \quad$ D. $\quad$ E.2014/5768, K.2015/118, 21.01.2015, (https://www.lexpera.com.tr/, Lexpera İçtihat Bilgi Bankası).

67 Bu konuda bkz. Yunus Eraslan ve S. Sacit Boz, “İdari Yargilama Usulünde İncelenmeksizin Ret Kararları," Türk İdare Dergisi 91, no. 488 (2019): 208.

68 Bkz. Nur Kaman, "Mahalli idarelerin Yetkilerinin ve Sınırlarının Kaynağ1 Olarak Mahalli Müşterek İhtiyaç," İstanbul Medipol Üniversitesi Hukuk Fakültesi Dergisi 7, no. 1 (2020): 80. 
sayılı Kanun uyarınca belediye ve mücavir alan sinırları içerisinde gecekonduların tespitinin belediyelerce yerine getirileceği öngörülmüştür. Şayet belediye ve mücavir alan sınırları dışında gecekondulaşmanın varlığı söz konusu ise; bu durumda söz konusu gecekonduların tespiti işlemi TOKİ tarafından yerine getirilecektir. Kanunkoyucu burada il özel idarelerine görev vermemiş; belediye ve mücavir alan sınırları dışında kalan bölgedeki gecekonduların tespitiyle ilgili olarak TOKİyi görevlendirmiştir. TOKİnin bunun yanı sıra tespit şekli ve esaslarına ilişkin görevleri de bulunmaktadır. Nitekim 775 sayılı Kanun md. 16/7'ye göre "gerek gecekondu bölgelerinin gerekse ıslah veya tasfiye edilecek gecekonduların tesbit şekli ve esasları, mahalli özellikler ve teknik imkânlar da göz önünde tutularak, Toplu Konut İdaresi Başkanlığınca tayin olunur". Bu doğrultuda gerek gecekonduların münferit olarak gerekse gecekondu islah ve tasfiye bölgelerinin tespiti TOKI tarafından yapılacaktır. Bununla birlikte, ilgili yasal düzenleme çerçevesinde "mahalli özelliklerin" de gözetilerek gecekondu islah ve tasfiye bölgelerinin özelliklerinin tespit edilmesi gerektiği dikkate alındığında; AY md. 127 kapsamında69 "mahalli idare" olarak "il özel idarelerinin" yer alması daha isabetli olacaktır.

Gecekondu Kanunu Yönetmeliği md. 69 uyarınca önleme bölgesi, 1slah bölgesi ya da tasfiye bölgesi ifadesinden "imar planlarında Gecekondu Kanununa istinaden bu maksatla ayrıldıkları açıkça belirtilmiş olan bölgeler kastedilmektedir". Bu anlamda bu bölgelerin tespit edilmesi bakımından idari makamlarca yapılan arazi planlaması faaliyetinin de önemi bulunmaktadır. ${ }^{70}$ Ancak,

69 AY md. 127/1: "Mahallî idareler; il, belediye veya köy halkının mahallî müşterek ihtiyaçların karşılamak üzere kuruluş esasları kanunla belirtilen ve karar organları, gene kanunda gösterilen, seçmenler tarafindan seçilerek oluşturulan kamu tüzelkişileridir".

70 Nitekim Gecekondu Kanunun Uygulama Yönetmeliği md. 86/1 uyarınca ıslah ve tasfiye bölgelerinin tespitinde belirli esasların göz önünde 
gecekondu yapılarının yoğun olduğu bölgelere yönelik yapılan sslah imar planlarıyla ${ }^{71}$ bu alanların yenilenerek kent mekanına katılması, bir yandan yapı maliklerine ait unsurların kent piyasasına dahil edilmesini diğer yandan bu bölgede malik olmayan kişilerin yeni konut arayışı ihtiyacının oluşmasına sebebiyet vermektedir. ${ }^{72}$ Dolayısıyla oluşabilecek bu gibi sorunların önüne geçilmesi bakımından gerek belediyeler gerekse TOKİ tarafından tespit edilecek bölgelerde planlama ve mahalli müşterek ihtiyaçların belirlenmesi ve karşılanması hususları önem taşımaktadır. Özellikle daha önce izlenen popülist yaklaşımların terk edilmesi; ilgili yasal düzenlemeler çerçevesinde gecekondu alanlarının yeniden yapılandırılmasına yönelik faaliyette bulunmasını gerektirmiştir. ${ }^{73}$ Belediyelerin söz konusu bölgelerde yapacağ kentsel mekanlara; (i). sağlıklı yeni konutların yapılması ve bu kapsamda ilgili arsanın tahsisi, (ii). kentsel rantın önüne geçilmesi bakımından kentiçi ekonomik görevlerinin bulunduğundan bahsedilebilir. ${ }^{74}$ TOKİnin de buna koşut biçimde pozitif yükümlülükleri bulunsa da doktrinde Keleş'in ifade ettiği şekilde; “TOKİ ülkede konut politikasının her yönüyle

tutulduğu ifade edilmektedir: "1- Afete maruz sahalar, 2- Gayri sihhi ve iskana müsait olmayan sahalar, 3- Tarihi ve turistik sahalar, 4- Amme hizmetlerinin götürülmesine imkan olmayan veya çok gayri iktisadi olan sahalar, 5- Normal şehircilik prensipleri içerisinde tahsisi mümkün olmayan sahalar, 6Gecekondu ıslah bölgesi olarak ayrılması arsa kıymeti bakımından gayri iktisadi olan sahalar".

71 Islah imar planları hakkında bkz. Halil Kalabalık, Imar Hukuku Dersleri (Ankara: Seçkin Yayıncılık, 2019), 167; Mustafa Genç, İmar Hukuku (Ankara: Seçkin Yayıncılık, 2015), 64.

72 Mehpare Çaptuğ, İdare Hukuku Açısından Kentsel Dönüşüm (Ankara: Seçkin Yayıncilık, 2016), 49.

73 Erman, "Formalization by the State, Re-Informalization by the People," 429.

74 Fikret Toksöz, "Yerel Yönetim ve Kentsel Ekonomik Sektöre Müdahale," Mimarlik Dergisi 15, no. 2 (1977): 51. 
sahibi değil, uygulanmasında özellikle teknik ve akçal yönlerden yardımcı olması gereken bir kuruluş olmak durumundadır". ${ }^{75} \mathrm{Bu}$ anlamda belediyelerin yanında ilgili gecekondu önleme ve islah bölgelerinde, kentsel altyapı vb. hizmetlerin sağlanması ve bunun için ayrılan bütçenin kullanılması bakımından TOKİ'nin önemli bir işlevi bulunduğu belirtilmelidir. ${ }^{76}$

\section{B. Uygulama Süreci}

775 sayılı Kanun kapsamında "iyileştirme", "tasfiye" ve "önleme" unsurları bir arada bulunmakta ve uygulamada da bu doğrultuda hareket edilmektedir. ${ }^{77} \mathrm{Bu}$ kapsamda yetkili idari makamlar tarafından söz konusu bölgelerin tespit edilmesini müteakip uygulama aşamasına geçilmektedir. Danıştay kararlarına bakıldığında örneğin gecekondu önleme bölgelerinde yapılan uygulamalara dair "dolaylı da olsa gecekondu yapımının önüne geçilmesinin hedef tutulduğu ve konut yapma işinin de bu kapsamda gerçekleştirildiğgi"78 ifade edilmektedir. Bununla birlikte, gecekondu önleme bölgelerinde daha ziyade yeni konut yapılması ve bu sayede gecekondulaşma olgusunu doğuran konut ihtiyacının giderilmesinin ön planda olduğu söylenebilecektir. ${ }^{79}$ Gecekondu tasfiye ve islah bölgelerinde ise; (i). gecekondu yapılarının ortadan kaldırılması, (ii). bu yapıların

75 Keleş, 100 Soruda Türkiye'de Kentleşme, Konut ve Gecekondu, 348.

76 Kaya, "Gecekondu Sorunu ve Gecekondu Kanunu," 877.

77 Dan. 6. D. E.2015/9450, K.2018/5043, T.23.05.2018, Kazancı İçtihat Bilgi Bankası.

78 Dan. 9. D. E.2015/511, K.2018/3514, T.28.05.2018, Kazancı İçtihat Bilgi Bankası.

79 Bu kapsamda önleme amacının iki şekilde belirdiği ifade edilebilir: Bunlardan birincisi, sonradan yapılan gecekondu yapılarının yetkili idari makamlarca derhal yıktırılması, ikincisi ise konut ihtiyacının karşılanmasına yönelik tedbirlerin alınması ve bu yerlerde sağlıklı yapılaşmanın oluşturulmasıdır. Binali Tercan, “Günümüze Değin İmar Afları," Planlama Dergisi, no. 1-4 (1996): 7. 
kent dokusunda oluşturduğu olumsuz özelliklerin ortadan kaldırılmaya çalışılması, hedeflenmektedir. Bu anlamda, söz konusu bölgelerde yapılan uygulamalarda "amaçlanan unsur" yönünden ayrım bulunduğundan bahsedilebilir. Bunun yanında, gecekonduların yıkımı sürecinden sonra; tasfiyesi gerçekleştirilen yahut ıslah edilebileceğine karar verilen bölgeyle ilgili imar planlarının yapılması, yani planlama sürecine girilmesi söz konusu olmaktadır. Gecekondu önleme bölgelerinde ise, yapılacak yeni konutlar ve arsa tahsisi yapılması ve bu kapsamda planlama yapılması gereği ortaya çıkmaktadır. Bu kapsamda çalışmanın devamında, gecekondu ıslah ve tasfiye bölgeleri bakımından hangi hallerde yıkımın gerçekleştirildiği ve planlama sürecinin ne şekilde işlediği incelenecek; sonrasinda, gecekondu önleme bölgelerinde yapilan konut üretimi ve arsa tahsisi sürecine değinilecektir.

\section{Gecekondu Islah ve Tasfiye Bölgeleri Yönünden Yıkım Süreci}

Mevcut gecekonduların kent dokusu üzerinde yarattığ1 olumsuz etkilerin giderilmesi ve bu yapıların yoğun olduğu bölgelerin 1slah edilmesi, bu mümkün değilse tasfiyesine ilişkin olarak; 775 sayılı Kanun md. 18'de tespit edilen bu yapıların yıkılmasının gerektiği ele alınmıştır. 775 sayılı Kanun hem gecekondulaşma olgusunun hukuken kabul edilmesi hem de yürürlüğe girdikten sonra gecekondulaşmanın önüne geçilmesi yönünden 1950'li yıllarda izlenen kentleşme politikasında farklı bir yeri haizdir. ${ }^{80}$ Bununla birlikte 775 sayılı Kanun'daki yıkım süreci, gecekonduların yapılacağı yerin kamu tüzelkişilerine ait olması yahut özel hukuk kişilerine ait olmasına göre

80 Kaya, “Gecekondu Sorunu ve Gecekondu Kanunu," 868. 
farklılaşmaktadır. ${ }^{81}$ Nitekim kamu tüzelkişilerine ait bir arsada yapılan gecekonduların "hiçbir karara gerek kalmaksızın derhal yıkımı" öngörülmüşken; özel hukuk kişilerinin arsalarında yapılan gecekondularda yıkım için arsa malikinin yazılı başvurusu gerekmektedir. ${ }^{82} 775$ sayılı Kanun kapsamında yıkımın gerçekleştirilebilmesi için ise; Danıştay kararında belirtildiği şekilde, "kamu idarelerinin izni olmaksızın yapılan ve gecekondu niteliği taşıyan yapının bulunması ve bu yapının da inşa edildiği parselin mülkiyetinin ihtilafsız olarak kamu idarelerine ait bulunması gerektiği kuşkusuzdur". 83

Bunun yanında gecekonduların yıkımı gerçekleştirilirken o yapının içinde bulunduğu bölgenin hukuki niteliği de önem arz etmektedir. Yıkım sürecinde ön planda olan tasfiye bölgeleri, doktrinde Eke'nin ifade ettiği üzere; "ıslahın mümkün olmadı̆̆ veya ekonomik olmadığı konumlar, jeolojik sakıncalı alanlar veya bir başka önemli kullanım için gerekli alanlar"84 olarak tanımlanmaktadır. Başka bir deyişle, mevcut gecekonduların oluşturduğu yapı topluluğu nedeniyle "mevcut planl yerde bir ıslah imar planı yapılmasının mümkün olmadığı, gecekonduların bulunduğu alanın böyle bir çalışmayı gerektirmeyecek bir sahada bulunması" 85 söz konusu ise iyileştirmeye yönelik uygulamaların yerine tasfiye uygulaması ön planda olacaktır. Bu gibi hallerde,

81 Tekin Akıllığlu, “Yıkma Kararlarında Yöntem Sorunları,” Amme İdaresi Dergisi 12, no. 4 (1979): 52.

82 Bununla birlikte 1976 yılında çıkarılan 1990 sayılı Kanun'la 775 sayılı Kanun'un yürürlüğe girmesinden sonra o ana kadar belediyelere ait olan ya da belediyelerin mülkiyetinde olması gereken arsalarda yapılan gecekondulara da af tanınmıştır. Akıllıŏ̆lu, "Yıkma Kararlarında Yöntem Sorunlar1," 52.

83 Dan. 6. D. E.2010/7816, K.2010/11274, T.14.12.2010, Kazancı İçtihat Bankası.

84 Eke, “Gecekondu Alanlarının Değerlendirilmesine İlişkin Çözümler,” 47.

85 Dan. 6. D. E.1992/4808, K.1993/4016, T.11.10.1993, Kazancı İçtihat Bilgi Bankası. 
idari makamların pozitif hukuk kurallarıyla kendilerine verilen görevleri yerine getirirken kullandığı kamu gücü ayrıcalığının bir tezahürü de yıkım uygulamaları açısından ortaya çıkmaktadır. ${ }^{86}$ Gecekondu yapılaşmasının yoğun olduğu ve ıslahının mümkün olmadığı bölgelerde yıkım uygulamaları kanunda belirtilen yöntemlere uygun biçimde gerçekleştirilmelidir. ${ }^{87}$ Zira yıkım uygulaması, hukuka aykırı yapının ortadan kaldırılmasının yanında, bireylerin temel hak ve hürriyetlerini "zedeleyebilecek" nitelikte olduğundan; hukuka uygun yöntemlerin izlenmemesi ilgilileri önemli ölçüde olumsuz etkileyecektir. ${ }^{88}$ Dolayısıyla gecekondu islah ve tasfiye bölgelerinde yapılacak uygulamalar yönünden ıslahın mümkün olup olamayacağı değerlendirilmesinin yapılması gerekmektedir. ${ }^{89}$

775 sayılı Kanun md. 22'de gecekondu 1slah bölgelerinde yer alan gecekonduların hangi hallerde ve hangi süreç izlenerek yıktırılacağı belirlenmiştir. Genel kaide, gecekonduların oluşturduğu sağlıksız kent dokusunun yıkım süreci neticesinde ortadan kaldırılarak düzenli şehirleşmenin sağlanmasıdır. ${ }^{90}$ Nitekim 775 sayılı Kanun md. 18 uyarınca belediye, Hazine, özel idarelere, genel ve katma bütçeli idarelere ait olan arazi ve

86 A. Kürşat Ersöz, "Bir İdari İşlem Olarak Yıkım Kararı,” Gazi Üniversitesi Hukuk Fakültesi Dergisi 19, no. 3 (2015): 104.

87 Akıllığlu, "Yıkma Kararlarında Yöntem Sorunları," 41.

88 Akıllıŏlu, "Yıkma Kararlarında Yöntem Sorunları," 41.

89775 sayılı Kanun'da "belediyelere, Hazineye, özel idarelere, katma bütçeli dairelere ait arazi ve arsalarda veya Devletin hüküm ve tasarrufu altında bulunan yerlerde yapılacak, daimi veya geçici bütün izinsiz yapılar, inşa sırasında olsun veya iskân edilmiş bulunsun, hiçbir karar alınmasına lüzum kalmaksızın, belediye veya Devlet zabıtası tarafından derhal yıktırılacă̆ı" ifade edildiğinden; burada yıkım uygulaması yönünden izlenen usul, 3194 sayılı Kanun md. 32 kapsamında yapılan uygulamadan farklılık arz etmektedir. Bkz. Ersöz, "Bir İdari İşlem Olarak Yıkım Kararı," 145.

90 Örücü, Sosyal Refah Devletinde Bir Sosyal Kamu Hizmeti Konut, 103. 
arsalarda veya Devletin hüküm ve tasarrufu altında bulunan yerlerde yapılacak daimi ve geçersiz yapılar inşa seviyesine bakılmaksızın derhal yıkılacaktır. ${ }^{91} 775$ sayılı Kanun yürürlüğe girdikten sonra ilgili alanlar üzerine inşa edilmeye çalışılan yapının tespitini müteakip yıkımına girişilecektir. Ancak, belli hallerde gecekondunun yıktırılmayarak, sahipleri tarafından yeniden 1slah ve imar edilmesi öngörülebilir. Bu halde, gecekondu sslah bölgesi olarak tespit edilen yer sinırları içerisinde, belediyeye ait olan veya belediyenin mülkiyetine geçmesi gereken arsa ve arazi üzerinde olan ve 775 sayılı Gecekondu Kanunu yürürlüğe girmezden önce yapılan gecekondulardan bu alanlar için yapılacak imar ve ıslah planları doğrultusunda olduğu gibi ya da değiştirilerek korunması mümkün olanlar hakkında derhal yıkım yapılmaz (Gecekondu Kanunu md. 22). Bu ihtimalde, imar sslah planının tanziminden sonra yapılacak bildiriden itibaren gecekondu, sahiplerince iki yıl içinde imar ve sslah edilir. ${ }^{92}$

91775 sayılı Kanun md. 18/1: “Bu kanunun yürürlüğe girdiği tarihten sonra, belediye sinırlarn içinde veya dışında, belediyelere, Hazineye, özel idarelere, katma bütçeli dairelere ait arazi ve arsalarda veya Devletin hüküm ve tasarrufu altında bulunan yerlerde yapılacak, daimi veya geçici bütün izinsiz yapılar, inşa sırasında olsun veya iskan edilmiş bulunsun, hiçbir karar alınmasına lüzum kalmaksızın, belediye veya Devlet zabıtası tarafindan derhal yıktırilı".

92775 sayılı Kanun md. 22: “Gecekondu islah bölgelerinde bulunup da, belediyelere ait olan veya bu kanun uyarınca belediyelerin mülkiyetine geçmesi gereken arazi ve arsalar üzerinde, bu kanunun yürürlüğe girdiği tarihten önce yapılmış olan gecekondulardan, bu sahalar için yapılacak imar ve islah planlarn ve mevzuat icaplarına göre olduğu gibi veya değiştirilerek korunması mümkün olanları, planın tanziminden sonra yapılacak bildiriden itibaren en geç 2 yıl içinde yönetmelik esasları dairesinde sahipleri tarafindan imar ve islah edilir. Aksi halde, bu yapularm verilen süre zarfinda yıktırılması yoluna gidilir. Sahipleri tarafından yıktırılmıyan yapılar, enkazı sahiplerine ait olmak üzere belediyelerce yıktırılır ve yıkım masrafi \% 10 fazlasiyle ilgiliden alını". 
Başta AY md. 17 ve md. 56 hükümleri olmak üzere, 3194 sayılı İmar Kanunu md. $1^{93}$ ile Planlı Alanlar İmar Yönetmeliği md. $1^{94}$ ve Plansız Alanlar İmar Yönetmeliği md. 1' de ${ }^{95}$ ifade edildiği üzere bireylerin sağlıklı ve dengeli bir çevrede yaşamaları için yapılacak yapıların şehircilik ilkeleri, planlama esasları ve fen normlarına uygun biçimde oluşturulması gerekmektedir. Devletin hüküm ve tasarrufu altında veya Hazine, belediye gibi idarelere ait arazi ve arsalarda izinsiz, yapılaşmaya uygun olmayan yapıların inşa edilmesi, imar kolluğu alanında korunan bir unsur olarak estetik unsurunu bozacak niteliktedir. ${ }^{96} \mathrm{Bu}$ çerçevede belediyelerin gerçekleştireceği bu yıkım, idari faaliyetlerden kolluk faaliyeti içerisinde kalmakla birlikte resen icra uygulamasının da bir örneğini teşkil etmektedir. ${ }^{97} \mathrm{Bu}$ kapsamda gecekondulaşmanın izinsiz ve uygun olmayan biçimde söz konusu arazi ve arsalarda yapılmasının önüne geçilmesi maksadıyla belediyece resen icra usulüyle yıkımın gerçekleştirileceği öngörülmektedir..$^{98}$ Bununla

933194 sayılı Kanun md. 1: "Bu Kanun, yerleșme yerleri ile bu yerlerdeki yapılașmalarm; plan, fen, sağllk ve çevre şartlarma uygun teșekkülünü sağlamak amacıyla düzenlenmiştir". (Metnin altı tarafımca çizilmiştir.)

94 Planlı Alanlar İmar Yönetmeliği md. 1: “Bu Yönetmeliğin amacı; plan, fen, sağlık ve sürdürülebilir çevre șartlarma uygun yapı ve yapılașma ile projelendirmeye ve denetime ilişkin usul ve esaslar belirlemektir". (Metnin altı tarafımca çizilmiştir.)

95 Plansız Alanlar İmar Yönetmeliği md. 1: “Bu Yönetmeliğin amacı belediye ve mücavir alan sınırlar içinde ve dışında kalan ve plânı bulunmayan alanlardaki yapılaşmaların fen, sağllk ve çevre şartlarına uygun teşekkülünü sağlamaktır". (Metnin altı tarafımca çizilmiştir.)

96 Özge Okay Tekinsoy, İdare Hukukunda Kamu Düzeni Kavramı (İstanbul: On İki Levha Yayıncılık, 2011), 147.

97 İl Han Özay, Günışı̆̆ında Yönetim (İstanbul: Filiz Kitabevi, 2004), 741.

98 Gecekondu Kanunu md. 18'den farklı olarak gecekondu islah ve tasfiye bölgelerinde yıkım işleminin, belli hallerin mevcudiyedi halinde, istisnasına da yer verilmiştir. Gecekondu Kanunu'nun 21. maddesinin 1. fikrasına göre "Belediyelere ait olan veya bu kanun uyarnca belediyelerin 
birlikte gecekonduların yıkımına dair idari makamın almış olduğu kararın idari ceza niteliğinde olduğu söylenemeyecektir. Zira burada yasal düzenlemenin idari makamlara resen icra, yani doğrudan yerine getirme konusunda yetki verdiği görülebilmekte olup, "cezalandırma” amacı söz konusu değildir.99 $\mathrm{Bu}$ nedenledir ki; idari makamlar, gecekondu yapılarının oluşturduğu sağlıksız yapılaşma olgusu neticesinde bozulan kamu düzenini, doğrudan geri getirebilmektedir. ${ }^{100}$

İdari makamlar tarafından gerçekleştirilen yıkım faaliyeti, kent içerisinde estetik vb. mülahazalarla kentleşme ve şehircilik ilkelerine uygun olmayan gecekondu yapılarının malikleri yönünden mülkiyet hakkına ve yerleşme hürriyetine müdahale niteliği taşımaktadır. ${ }^{101}$ Şüphesiz, bu şekilde temel hak ve hürriyetlere müdahale teşkil eden bir idari faaliyet söz konusu olursa; bunun AY md. 13 kapsamında bir yasal dayanağının bulunması icap eder. ${ }^{102}$ Bununla birlikte, ilgili konuda bir Danıştay kararına bakıldığında; gecekonduların yıkımına dair alınan idari kararlar bakımından farklı kanunlara dayanılması,

mülkiyetine geçmesi gereken arazi ve arsalar üzerinde, bu kanunun yürürlüğe girdiği tarihten önce yapılıp, 16'ncı ve 17'nci maddelere göre tesbit edilmiş bulunan gecekondulardan konut olarak kullanulanları; içinde oturanlar 25'inci maddedeki şartları haiz oldukları takdirde; a) Gecekondunun sahibi ise, gecekondusuna karşılık gelecek şekilde, borçlanma suretiyle veya sair şekillerde konut verilinceye veya nakde dönüştürülüp ödeninceye veya konut yapmak üzere arsa tahsis edilip lüzumu halinde kredisi sağlanmak suretiyle, 27'nci maddedeki süre ve şartlara uygun olarak konutunu yapıncaya kadar, b) Gecekondunun sahibi değil ise, ucuz kiralık konut temin edilinceye veya konut yapmak üzere arsa tahsis edilip, lüzumu halinde kredisi sağlanmak suretiyle 27'nci maddedeki süre ve şartlara uygun olarak konutunu yapıncaya kadar, yıktırılamaz".

99 Özay, Günışı̆̆ında Yönetim, 741.

100 Özay, Günışı̆̆ında Yönetim, 741.

101 Fethiye Nur Akkaya, Kent Estetiğini Koruma Amaçlı İdari Kolluk Faaliyeti (İstanbul: On İki Levha Yayıncilık, 2016), 86-87.

102 Kemal Gözler, Türk Anayasa Hukuku (Bursa: Ekin Yayınevi, 2018), 308. 
doğrudan o kararın hukuka aykırılığına yol açmamaktadır. ${ }^{103}$ Oysa doktrinde Yasin'in vurguladığı üzere, "yıkım kararı ancak hukuki dayanağı olan mevzuatta belirtilen hususların gerçekleşmesi halinde başvurulacak bir yöntemdir" ${ }^{104}$ Bu nedenle 775 sayılı Kanun kapsamında alınması gereken bir yıkım kararının; bu husus atlanarak doğrudan 3194 sayılı Kanuna dayandırılması, yasal dayanağın farklı şekilde ifade edilmesi manasına geleceğinden hukuka aykırılık teşkil etmektedir. ${ }^{105}$

\section{Gecekondu Islah, Tasfiye ve Önleme Bölgelerinde Planlama Süreci}

2981 sayılı Kanun'la getirilen affın genişletilmesine yönelik biçimde ihdas edilen 3290 sayılı Kanun' da ${ }^{106}$ sslah imar planıyla belirlenen alanlarda gecekondu yapılarına ilişkin doğrudan tapu verilebileceği ifade edilerek, bu yapıların piyasaya dahil edilmesi söz konusu olmuştur. ${ }^{107}$ Daha sonrasında ihdas edilen 3414 sayılı Kanun ${ }^{108}$ ise, bu yapıların devrini kolaylaştırmış ve sslah imar planlarıyla ilgili olarak ilçe belediyelerine yetki

103 Dan. 6. D. E.2003/1984, K.2004/5538, T.10.11.2004, DD. no. 109, 214, aktaran; Melikşah Yasin, Imar Hukukunda İdarenin Yıkma Yetkisinin Kullanımının Usul ve Esasları (İstanbul: On İki Levha Yayıncılık, 2009), 20. Ayrıca bkz. Dan. 14. D. E.2017/22, K.2018/6600, T.13.11.2018, Kazancı İçtihat Bilgi Bankası. Ancak Danıştay'ın bu konuda farklı yönde kararları da mevcuttur. Bkz. Dan. 14. D. E.2011/4939, K.2012/695, T.08.02.2012, Kazancı İçtihat Bilgi Bankası; Dan. 14. D. E.2011/10144, K.202/6943, T.10.10.2012, Kazancı İçtihat Bilgi Bankası.

104 Yasin, Imar Hukukunda İdarenin Yıkma Yetkisinin Kullanımının Usul ve Esaslarl, 20.

105 Yasin, Imar Hukukunda İdarenin Yıkma Yetkisinin Kullanımının Usul ve Esaslari, 21.

106 RG. 07.06.1986, S. 19130.

107 Bkz. Tercan, "Günümüze Değin İmar Afları," 8.

108 RG. 11.03.1988, S. 19751. 
tanımıştır. ${ }^{109} \mathrm{Bu}$ nedenle, söz konusu yasal düzenlemeler çerçevesinde belirli gecekonduların muhafaza edilmesinin önünün açılması, ${ }^{110}$ gecekondu sorununun çözülmesinden ziyade artmasına neden olmuş ve planlama ihtiyacını doğurmuştur. ${ }^{111}$ Zira gecekondulaşma olgusuna karşı izlenen politikada mevcut gecekonduların yasallaştırılarak, bundan sonraki dönemlerde buna izin verilmeyeceği ifade edilse de bunun sıkça tekrarlanması ve gecekonduların alım-satım sözleşmelerine konu edilebilmesi sonucu, yöntemin yetersiz olduğu ortaya çıkmıştır. ${ }^{112}$ Dolayısıyla 2981 sayılı Kanun'un genel amacinın her ne kadar "imar affina tabi gecekondularm zenginleşme aracı olmadı̆̆̆l, barınma amaçlı olarak kullanılması gerektiği"'113 yönünde olduğu belirtilse de buna uygun hareket edilmemiştir. Bu doğrultuda esasen doktrinde Sancakdar'ın vurguladığı üzere; yasal düzenlemelere uymayan ve bundan dolayı bazı kişilere ekonomik çıkar sağlayabilen imar affı kanunlarının desteklenmesinin kabulü mümkün değildir. ${ }^{114}$ İfade etmek gerekirse, bu yasal düzenlemelerin yarattığ1 çelişkiler bir yana, sorunun çözülememesinde gerekli şehir planlama faaliyetinin iyi yapılamaması önemli bir etken

109 Eke, “Gecekondu Alanlarının Değerlendirilmesine İlişkin Çözümler,” 49.

110 Neşe Erkelli Kızıl, “2981 Sayılı İmar Affı Kanunu ve Bu Kanuna Dayanılarak Kurulan Yeminli Özel Teknik Büroların Faaliyet Süreci," İdare Hukuku ve İlimleri Dergisi 4, no. 1-3 (1983): 74.

111 Tercan, "Günümüze Değin İmar Afları,” 8.

112 M. Murat Erdoğan ve Murat Ömürgönülşen, “Yeminli Özel Teknik Bürolar: Gecekondu Sorunu, İmar Affı ve Kamu Hizmetlerinin Özel Kişilere Gördürülmesi Açısından Bir Değerlendirme," Hacettepe Üniversitesi İktisadi ve İdari Bilimler Fakültesi Dergisi 7, no. 1-2 (1989): 177.

113 Dan. 14. D. E.2015/9128, K.2018/1254, T.08.03.2018, Kazancı İçtihat Bilgi Bankası.

114 Oğuz Sancakdar, Belediyenin Imar Planını Yapması-Değiştirmesi ve Íptal Davası (Ankara: Yetkin Yayıncılık, 1996), 167. 
olmuştur. ${ }^{115}$ Gerçekten "her bağış̧lama, o güne kadar yapılanları hukuksallaştırarak önlemeyi amaçlamaktadır. Uygulamadan edinilen deneyimler göstermektedir ki, imar suçlarının bağışlanması (imar affi), gecekondu ve kaçak yapılaşmayı önleyeceğine özendirmekte ve bir süre sonra yenisinin çıkacă̆ı beklentisine yol açmaktadır". ${ }^{116}$

Kent mekanlarının iyileştirilmesi yahut sağlıklı yapılaşmanın oluşturulması; planlama faaliyetinden bağımsız biçimde gerçekleştirilemez. ${ }^{117}$ Doktrinde Yayla'nın aktardığı üzere şehir planlaması; "şehirsel yerleşmelerin, mevcut ve gelecekteki, tabii, kültürel, iktisadî ve sosyal şartlarda bir düzen içinde bağdaştırılması için gerekli işlem ve eylemlerle, örgütlenme çabalarının tümünü"118 ifade eder. Bu doğrultuda, AY md. 56'da öngörülen sağlıklı ve dengeli bir çevrenin var olabilmesi için; şehircilik ilkeleri ve fen normlarina ve planlama esaslarına uygun planlamanın yapılması önem arz etmektedir. Bu nedenle gecekondu islah ve tasfiye bölgeleri ile ilgili olarak mevcut imar planlarının yeniden gözden geçirilmesi gerekmiştir. Nitekim 775 sayılı Kanun md. 16 ve Gecekondu Kanunu Uygulama Yönetmeliği md. 86 kapsamında gecekondu sslah ve tasfiye bölgelerinin tespit edilmesini müteakip halk konutu veya nüve konut yapımına tahsis edilecek sahaların seçimi, haritaların hazırlanması, imar ve sslah planlarının düzenlenmesi gerekmektedir. Aynı doğrultuda, 2981 sayılı Kanun md. 13'e göre imar planı olan yerlerde mevcut imar planları gerektiği

115 Yücel Ünal, Türk Şehir Planlama Hukukunun Bugünü (1985-2015) (İstanbul: Legal Yayıncılık, 2015), 187.

116 Erdal Köktürk, “Türkiye' de Gecekondu ve İmar Affı Üzerine Bir İnceleme,” Jeodezi, Jeoinformasyon ve Arazi Yönetimi Dergisi, no. 2003/89 (2003): 52.

117 P. Pınar Özden ve A. Sema Kubat, “Türkiye'de Şehir Yenilemenin Uygulanabilirliği Üzerine Düşünceler," İTÜ Dergisi/a 2, no. 1 (2003): 79.

118 Yıldızhan Yayla, Şehir Planlamasının Başlıca Hukukî Meseleleri ve İstanbul Örneği (İstanbul: İstanbul Üniversitesi Hukuk Fakültesi Yayınları, 1975), 9. 
takdirde 1slah imar planları şeklinde yeniden düzenlenir. ${ }^{119}$ Yapılan bu arazi planlaması faaliyeti neticesinde ortaya çıkarılan en önemli sonuçlardan birisi ise bu planlara idari makamlar tarafından uygulama zorunluluğunun bulunmasıdır. ${ }^{120}$ Ancak, belirli bölgelerde birden fazla imar planının bir arada bulunması ${ }^{121}$ ve sonrasında çıkarılan imar affı yasaları; bu zorunluluğun adeta "silikleşmesine" sebebiyet vermiştir. Ayrıca sslah imar planlarında mevcut durumun dikkate alınması zorunluluğunun bulunmaması, kent mekanlarında yaşanan değişimin benimsenmesini zorlaştırmış ve bazı gecekonduların muhafaza edilerek alım-satım sözleşmelerine konu olmasına, "80'li yillarm ortalarından itibaren kentsel rant dağıtım aracına"122 dönüşmesine yol açmıştır. Bu nedenlerle kentsel mekanlarda yaşanan dönüşümler neticesinde gecekondulaşma olgusuyla yapılan mücadele, tam manasıyla amacına ulaşamamıştır. ${ }^{123}$

Yetki bakımından belirtmek gerekirse, 3194 sayılı Kanun uyarınca Çevre ve Şehircilik Bakanlığı, "gerekli görülen hallerde Gecekondu Kanununun uygulanmasi amacıyla yapulmasi gereken planların ve plan değisşikliklerinin ilgili belediyelere veya diğer idarelere

1192981 sayılı Kanun md. 13/1 (c) "Islah imar planları belediye veya valiliklerce mümkün olduğu kadar fiili durum dikkate alınarak ve yapılanma şartları da belirlenerek yapılır veya belediye veya valiliklerce Yeminli Özel Teknik Bürolara yaptırilır. En geç 1 ay içinde belediye meclislerince kabul edilenler belediye meclislerince, büyük şehir yönetiminde ilçe belediye meclislerince Kabul edilenler ilçe belediye meclislerince, il idare kurullarınca kabul edilenler valilikçe tasdik edilerek yürürlüğe girer. Bu planların tescili de 1 ay içinde ivedilik ve öncelikle yapılır. Imar planı olan yerlerde mevcut imar planları gerektiği takdirde ıslah imar planları şeklinde yeniden düzenlenir".

120 Yayla, Şehir Planlamasının Başlıca Hukukî Meseleleri ve İstanbul Örneği, 91.

121 Yayla, Şehir Planlamasının Başlıca Hukukî Meseleleri ve İstanbul Örneği, 93.

122 Kübra Cihangir Çamur, "İmar Islah Planlarının Ankara Kent Makroformu Üzerindeki Yoğunluk Etkileri," Planlama Dergisi, no. 1-4 (1996): 15.

123 Cihangir Çamur, "İmar Islah Planlarının Ankara Kent Makroformu Üzerindeki Yoğunluk Etkileri," 15. 
bu yolda bilgi vererek ve gerektiğinde iş birliği sağlayarak yapmaya, yaptırmaya, değisstirmeye ve re'sen onaylamaya yetkili" olduğu ifade edilmiştir. ${ }^{124}$ Bunun yanında 2985 sayılı Kanun ${ }^{125}$ uyarınca TOKİnin "gecekondu bölgelerinin tasfiyesine veya iyileştirilerek yeniden kazanımına yönelik olarak gecekondu dönüşüm projeleri geliştirebileceği, inşaat uygulamaları ve finansman düzenlemeleri yapabileceği" belirtilmiştir. ${ }^{126}$ TOKİ bu kapsamda, "gecekondu dönüşüm projesi uygulayacă̆ı alanlarda veya mülkiyeti kendisine ait arsa ve arazilerde veya valiliklerce toplu konut iskan sahası olarak belirlenen alanlarda çevre ve imar bütünlüğ̈̈nü bozmayacak şekilde her tür ve ölçekteki planlar ile imar planlarm yapmaya, yaptırmaya ve tadil etmeye" de yetkilidir. ${ }^{127} 775$ sayılı Kanun'da ise 1 slaha

124 Çevre ve Şehircilik Bakanlığı'nın 3194 sayılı Kanun kapsamında gecekondu alanlarında imar planı yapma yetkisi hakkında bkz. Gürsel Öngören, “Kentsel Dönüşüm İmar Planlamasında Yetki," Legal Hukuk Dergisi 11, no. 123 (2013): 14-15.

125 RG. 17.03.1984, S. 18344.

1262985 sayılı Kanun ek md. 7/1: “Başkanlık gecekondu bölgelerinin tasfiyesine veya iyileştirilerek yeniden kazanımına yönelik olarak gecekondu dönüşüm projeleri geliştirebilir, inşaat uygulamaları ve finansman düzenlemeleri yapabilir. Bu amaçla gecekondu bölgelerinde, gerçek kişilerin ve özel hukuk tüzel kişilerinin mülkiyetinde bulunan gayrimenkuller ile 24.2.1984 tarihli ve 2981 sayıl Imar ve Gecekondu Mevzuatına Aykırı Yapılara Uygulanacak Bazı İşlemler ve 6785 Sayılı İmar Kanununun Bir Maddesinin Değiştirilmesi Hakkında Kanuna göre hak sahibi olan kişilerin haklarına konu gayrimenkullerin değeri Başkanlık tarafindan tespit edilir ve Başkanlık bu kişilerle proje çerçevesinde anlaşmalar yapabilir. Bu anlaşmaların usul ve esaslarm belirlemeye Başkanlık yetkilidir".

1272985 sayılı Kanun md. 4/1: “Başkanlık, gecekondu dönüşüm projesi uygulayacă̆ı alanlarda veya mülkiyeti kendisine ait arsa ve arazilerde veya valiliklerce toplu konut iskan sahası olarak belirlenen alanlarda çevre ve imar bütünlüğ̈̈̈nü bozmayacak şekilde her tür ve ölçekteki planlar ile imar planlarını yapmaya, yaptırmaya ve tadil etmeye yetkilidir. Bu planlar; büyükşehir belediye stnırları içerisinde kalan alanlar için büyükşehir belediye meclisi tarafindan, il ve ilçe belediye sınırları ile mücavir alanları içerisinde kalan alanlar için ilgili belediye meclisleri tarafindan, beldelerde ve diğger yerlerde ilgili valilik tarafindan, planlarm 
muhtaç veya tasfiyesi gereken gecekondu bölgeleri ile yeniden halk konutu veya nüve konut yapımına tahsis edilecek sahaların seçimi, haritalarının hazırlanması ve imar ve ıslah planlarının düzenlenmesi hususlarının TOKİ denetimi altında belediyeler tarafından yapılacağı ya da yaptırılacağı ifade edilmektedir. ${ }^{128}$ Bununla birlikte Danıştay'ın bir kararında belirtildiği üzere, TOKİ'nin bu kapsamdaki bazı yetkileri daha sonrasında Çevre ve Şehircilik Bakanlığı'na verilmiştir. ${ }^{129}$

$\mathrm{Bu}$ anlamda yukarıdaki açıklamalara bakıldığında; ilgili yasal düzenlemelerde gecekondu tasfiye ve sslah bölgelerinde yapılan arazi planlaması faaliyetlerinde TOKI ile Çevre ve Şehircilik Bakanlığı'na denetim ve tespite yönelik önemli yetkilerin verildiği ve fakat "gecekondu yapılarının yoğun olduğu bölgelerde yaşayan kişilerin sürece katılımı" hususuna yer verilmediği görülmektedir. Dolayısıyla gecekondu ıslah ve tasfiye bölgelerinde yapılacak planlama faaliyetleriyle ilgili olarak belediyelerin daha etkin bir rol üstlenmesi sağlanabilir. $\mathrm{Bu}$ sayede bireylerin katılımının daha fazla olduğu bir sistem

belediyelere veya valiliğe intikal ettiği tarihten itibaren üç ay içerisinde aynen veya değiştirilerek onaylanır (...)".

128775 sayılı Kanun md. 19: "Islaha muhtaç veya tasfiyesi gereken gecekondu bölgeleri ile yeniden halk konutu veya nüve konut yapımına tahsis edilecek sahaların seçimi, haritalarının hazırlanması, Imar ve ıslah planlarmın düzenlenmesi, Toplu Konut İdaresi Başkanlı̆̆ının denetimi altında, ilgili belediyelerce yapılır veya yaptırılır. Toplu Konut İdaresi Başkanlığı, hazırlanan harita ve planlar redde, düzeltilmek üzere geri göndermeye, olduğu gibi veya değiştirerek onaylamaya ve lüzum gördüğ̈̈ hallerde bu hizmetleri kendisi yapmaya veya yaptırmaya yetkilidir. Onaylanarak kesinleşen planlar belediye dairesinde herkesin görebileceği bir yerde bir ay süre ile asılır ve keyfiyet mutat vasitalarla halka duyurulur".

129 Bkz. Dan. 6. D. E.2015/9450, K.2018/5043, T.23.05.2018, DD. no. 149, 177. Ayrica bkz. Tamer Utkucu ve Elif Çağlan, Rant Imar İtibar (İstanbul: On İki Levha Yayıncılık, 2019), 82. 
geliştirilerek mevcut sorunun halli mümkün olabilecektir. ${ }^{130}$ Özellikle 1slah imar planları yönünden mevcut (fiili) durumun dışında da yerleşim planlaması yapıldığından; yapılan uygulamalar neticesinde kişilerin yaşadığı yerlere yabancılaşma endişesinin giderilmesi yönünden katılım ilkesinin sağlanması önem taşımaktadır. ${ }^{131}$

\section{Yeniden Arsa Tahsisi ve Yapılaşma}

Kentlerde gecekondu yapılarının oluşturduğu bölgelerin olumsuz özelliklerinin yanında, kişiler yönünden ortaya çıan başlıca sorunlardan birisi de iskan meselesidir. ${ }^{132}$ Gecekondulaşmanın önlenmesine yönelik bölgelerin tespit edilerek bu doğrultuda uygulamanın yapılarak konutu olmayan kişilere yeni konutların yapılacağ arz etmektedir. 775 sayılı Kanun, bu anlamda ileriye yönelik biçimde gecekondu önleme bölgeleri kapsamında şehirleşmenin nasıl olması gerektiğine dair hükümler ihtiva emektedir. ${ }^{133} \mathrm{Bu}$ doğrultuda, doktrinde Keleş'in de belirttiği şekilde önleme bölgeleri, "gecekondu yapımın önlemek amacıla, konutsuz yurttaşlara verilmek üzere, kent yönetimince konut yapımına elverişli duruma getirilen kent topraklarının bulunduğu kent kesimini"134 ifade eder. Bu kapsamda gecekondu önleme bölgelerinin tespit

130 Özellikle gecekondu dönüşüm bölgelerinde katılım hususunun sağlıklı şehirleşmenin sağlanmasına olumlu etkileri hakkında bkz. Mustafa Kara, “Türkiye'de Gecekondu Dönüşüm Projelerinin Konut Sorununun Çözümündeki Rolü: Ankara İli Gültepe ve Yatıkmusluk Örneği," Girişimcilik ve Kalkınma Dergisi 5, no. 2 (2010): 174.

131 Köktürk, “Türkiye' de Gecekondu ve İmar Affı Üzerine Bir İnceleme,” 57.

132 Orhan Tuna, "Türkiye'de Gecekondu Önleme Bölgeleri Hakkında Bir Araştırma ve Yeni Bir Model Taslağı," Sosyal Siyaset Konferansları (İstanbul: Bilmen Basımevi, 1977), 6.

133 Eke, “Gecekondu Alanlarının Değerlendirilmesine İlişkin Çözümler,” 47.

134 Keleş, Kentbilim Terimleri Sözlü̆̆̈̈, 102. 
edilmesinde; yeni konut yapilarak gecekondu sahiplerine verilmesi hususu ön plandadır. Nitekim bir Danıştay kararına konu olayda da yıkılacağı ya da yıkılması gerektiği tespit edilen gecekondu yapıları yönünden "belediye meclisi kararı ile de Ayază̆a gecekondu önleme bölgesinde, dere ıslah çalışma alanında kalan gecekondu hak sahiplerine 200 daire yapularak verilmesinin karar altına alındığgl"135 ifade edilerek bu hususa vurgu yapıldığı görülmektedir. Arsa tahsis şatlarını ele alan 775 sayılı Kanun md. 25 hükmünde de görüldüğ̈̈ üzere genel olarak, “önleme bölgelerindeki arsalarm öncelikle gecekondularm ıslahı ve tasfiyesi sebepleriyle açıkta kalacak veya diğer konutsuz kişilere verileceği" ${ }^{\prime \prime} 136$ ifade edilmiştir. Bu doğrultuda, böyle bir durumun varlığı; açıkta kalan ya da konutsuz olduğu tespit edilen kişilerin hukuki statüleri üzerinde etki doğurmakta ve sosyal hak çerçevesinde devlete karşı kişilerin talep hakkı gündeme gelebilmektedir. ${ }^{137}$

Özellikle 2981 sayılı Kanun'da, Danıştay kararlarında da ifade edildiği şekilde ${ }^{138}$, "hak sahibi olma niteliklerini taşıdı ̆̆̆ belirlenen kişilere, gecekondunun bulunduğu yerin yürürlükteki imar

135 Dan. 6. D. E.1992/1381, K.1993/387, T.12.02.1993, (https://legalbank.net/, Legalbank İçtihat Bilgi Bankası).

136775 sayılı Kanun md. 25: "7 nci madde gereğince tesbit olunan önleme bölgelerindeki arsalar, öncelikle gecekonduların ıslahı ve tasfiyesi sebepleriyle açıkta kalacaklara ve diğer konutsuz vatandaşlara verilir. Bu arsalardan, ıslah ve tasfiye bölgelerinde bulunan diğer yap sahiplerinden yapısının tasfiyesini istiyenler de faydalanabilirler. Her ne sebeple olursa olsun, bu kanun hükümlerince arsa tahsis edilecek kimselerin, yoksul veya dar gelirli olması, kendisinin veya eşinin veya ergin olmıyan çocuğunun herhangi bir belediye sınır içinde ev yapmaya müsait arsaya veya her hangi bir yerde bir ev veya apartmanın ayrı bir dairesine karşılık olan payına sahip bulunmaması şarttır. Kimlerin yoksul ve dar gelirli sayılacağl, kendisine arsa tahsis edileceklerin öncelik strası ve yukarda sözü geçen diğer hususlarm esaslarn yönetmelikte belirtilir".

137 Örücü, Sosyal Refah Devletinde Bir Sosyal Kamu Hizmeti Konut, 104.

138 Dan. 6. D. E.2019/3718, K.2019/5307, T.30.05.2019, Kazancı İçtihat Bilgi Bankası. 
planında konut olarak kullanılamamasi halinde, gecekondunun bulunduğu yerden değil, gecekondu önleme veya uslah bölgelerinden veya yakın bölgelerde yapılmış ıslah imar planları içinde meydana gelen boş imar parsellerinden müstakil, hisseli veya kat mülkiyeti esasına göre tahsis yapılması mümkün olacă̆ı" hükmüne yer verilmiştir. Dolayısıyla buradaki amaç, "fen ve şehircilik esaslarına uygun yapılaşmanın sağlandığı alanlara" yeni konutların yapılarak gecekondu bölgelerinde yaşayan kişilerin buraya yerleştirilmesidir. ${ }^{139} \mathrm{Bu}$ yönüyle "yeni yerleşim alanı olarak kullanılmak üzere" yetkili idari makamlarca tespit edilen, 775 sayılı Kanun'da tanımlanan "önleme bölgesinin" 6306 sayılı Kanun md. 2' de ifade edilen "rezerv yapı alani ${ }^{140 " ~ k a v r a m i n a ~}$ koşut olduğundan bahsedilebilecektir. Ancak, gecekondu önleme bölgelerinde bireylerin bu konuda bir karar alınması için idari makamlara başvurması yahut onları harekete geçirmesi hali söz konusu değildir. ${ }^{141} \mathrm{Bu}$ husus, özellikle gecekondu önleme bölgelerinde yapılan uygulamalarda katılım ilkesinin

139 Bu yöndeki uygulama örnekleri için bkz. Nurcan Yılmaz, "Portakal Çiçeği Vadisi ve Dikmen Vadisi Kentsel Dönüşüm Projeleri," Kentsel Dönüşüm Hukuku, der. Melikşah Yasin ve Cenk Şahin (İstanbul: On İki Levha Yayıncilik, 2015), 453.

1406306 sayılı Kanun md. 2: “Bu Kanunun uygulanmasında; (...) c) Rezerv yapı alanı: Bu Kanun uyarınca gerçekleştirilecek uygulamalarda yeni yerleşim alanı olarak kullanılmak üzere, TOKI'nin veya İdarenin talebine bağlı olarak veya resen Bakanlıkça belirlenen alanları (...) ifade eder". Ayrıca bkz. Onur Kaplan, İdare Hukuku Yönünden Afet Riski Altındaki Alanlarm Kentsel Dönüşüm Süreci (İstanbul: On İki Levha Yayıncılık, 2017), 266-267.

1416306 sayılı Kanun Uygulama Yönetmeliği md. 4/2 (c): “Gerçek veya özel hukuk tüzel kişilerince, birinci fikrada belirtilen bilgi ve belgeleri ihtiva eden dosyaya istinaden Bakanliktan rezerv yap alan belirlenmesi talebinde bulunulabilir. Gerçek veya özel hukuk tüzel kişilerince rezerv yapı alanı belirlenmesi talebinde bulunulabilmesi için; bu talebin, talebe konu taşınmazların maliklerinin tamamının muvafakati ile yapılması gerekir". 
tam manasiyla uygulanamamasina da sebebiyet vermektedir. ${ }^{142}$ Bunun dışında, söz konusu bölgelerde yapılacak uygulamalarda idari makamlarm "arsa bedelini aldıkları gecekondu önleme bölgesinde bulunan taşınmazi vermemesi ve yeni bir arsa da tahsis etmemesi"143 ise hukuka aykırı bir idari işlemin varlığına sebebiyet verecektir. Bu doğrultuda idari makamların şartların sağlanmasına rağmen tahsis işleminin gereğini yerine getirmemesi, idari faaliyetin işleyişinde bir aksaklığa sebep olacağından "kusur sorumluluğuna" da yol açar niteliktedir. ${ }^{144}$

Belirtmek gerekirse, önleme bölgeleri yönünden sağlıklı bir yapılaşmanın gerçekleştirilmesi amacı önemli rol oynadığından; hukuka aykırı yapının korunmasından ziyade "amaca uygun" hareket edilmesine ağırlık verilmektedir. Nitekim Danıştay tarafından verilen bir karara göre, "gecekondulaşmayı önlemeye yönelik bir alan olan gecekondu önleme bölgesi üzerinde yapilan gecekondular nedeniyle verilen tapu tahsis belgesinin iptaline ilişkin dava konusu işlemde hukuka aykırılık bulunma(maktadır)". ${ }^{145}$ Bunun yanında gecekondu önleme bölgelerinde yapılacak uygulamalarda, bazı Danıştay kararlarında 775 sayılı Kanun'a öncelik tanındığ1 da görülmektedir: "Bayındırlık ve İskan Bakanlığınca 1967 yılında 775 sayılı Yasa uyarınca Gecekondu Önleme Bölgesi olarak ilan edilmiş bulunan bu alanda kalan gecekondular nedeniyle daha sonra 2981 sayıl Yasa uyarinca yapılan af başvurusunun kabul edilmesi suretiyle tapu tahsis belgeleri düzenlenmiş ise de, 775 sayılı Yasa hükümlerinin uygulanması gereken

142 Bkz. Melikşah Yasin, “Kentsel Dönüşüm Uygulamalarının Hukuki Boyutu," Türkiye Barolar Birliği Dergisi, no. 60 (2005): 131.

143 UM. E.2014/715, K.2015/176, T.06.04.2016, RG. 30.04.2015， S. 29342 (Mükerrer).

144 Bahtiyar Akyılmaz, Murat Sezginer ve Cemil Kaya, Türk İdari Yargılama Hukuku (Ankara: Savaş Yayınevi, 2018), 522.

145 Dan. 6. D. E.2005/889, K.2007/2196, T.24.04.2007, Legalbank İçtihat Bilgi Bankası. 
bir alanda 2981 sayıl Yasa hükümlerine dayanılarak işlem tesis edilmesi mümkün değildir". ${ }^{146}$ Bu husus, özellikle 775 sayılı Kanun çerçevesinde yapılacak projelerde bütünlügün sağlanması açısından ve gecekondulaşmasının sonraki dönemlerde artışının önüne geçilmesi bakımından önem arz etmektedir. $\mathrm{Bu}$ bütünlüğün gerçekleştirilebilmesi için öncelikle boş kamu arazilerinin kullanılması, ${ }^{147}$ bu mümkün değilse tespit edilen bölgeler içerisinde kalan taşınmazların kamulaştırılması gündeme gelebilir. ${ }^{148}$ Bununla bağlantılı olarak, bu alanlarda proje bütünlüğünün sağlanması noktasında herhangi bir "acelelik" hali mevcut değilse; bu durumda olağanüstü hukuki müesseselere başvurulması düşünülemez. Yani, "daha iyi barınma koşullara sahip bölgelerin oluşturulması, dar gelirli kesime konut üretilmesinin sağlanması ve yeni gecekonduların yapımının engellenmesi amacıyla"149 acele kamulaştırma usulüne gidilmesi söz konusu değildir. Dolayısıyla gecekondu önleme alanlarında gerçekleştirilen uygulamalarla acele kamulaştırma arasında doğrusal bir bağlantı söz konusu değildir. ${ }^{150}$ Şu halde, meseleyi sadece konut üretiminde niceliği artırmak ya da ani ve fakat geçici çözümler yaratmak suretiyle ele almak yerine kentsel altyapının sağlandığı konut üretimi ve tahsis uygulamaları yönünden niteliğin ön planda olduğu bir yaklaşımla değerlendirmek gereklidir. ${ }^{151} \mathrm{Bu}$ sayede gecekonduların

146 Dan. 6. D. E.2001/5190, K.2002/5095, T.13.11.2002, Legalbank İçtihat Bilgi Bankası.

147 Dan. 6. D. E.1998/4212, K.1999/4217, T.04.10.1999, Kazancı İçtihat Bilgi Bankası.

148 Bkz. Yar. 5. HD. E.2013/3411, K.2013/13266, T.20.06.2013, Legal Hukuk Dergisi 12, no. 133 (2014): 265.

149 Dan. IDDGK. E.2019/3342, K.2020/148, T.30.01.2020, Kazancı İçtihat Bilgi Bankası.

150 Cenk Y. Şahin, Acele Kamulaştırma (İstanbul: On İki Levha Yayıncılık, 2018), 103.

151 Yasemin Alkışer ve Hülya Yürekli, “Türkiye'de Devlet Konutunun Dünü, Bugünü, Yarını," İTÜ Dergisi/a 3, no. 1 (2004): 64. 
yasallaştırılması, piyasaya konu olan bir rant aracı haline gelmesi ve tekrar önüne geçilmesini kapsayan bir döngünün içine girilmesi engellenmiş olacaktır.

\section{SONUÇ}

Sanayi Devriminin etkilerinin ileriki y1llarda etkilerini artırarak devam etmesi ve üretim biçiminin değişmesi neticesinde büyük kentlere göç eğilimi oluşmuştur. 1950'li yıllardan itibaren artan kentleşme olgusu karşısında Türkiye ölçeğinde altyapının yetersiz oluşu ve kalıcı çözümlerin üretilememesi sorunların daha karmaşık hale bürünmesine sebebiyet vermiştir. Özellikle kentleşme hareketinin artması karşısında gerekli konut ihtiyacının sağlanamamış olması gecekondulaşmanın artmasına neden olmuştur. Yapılan gecekonduların şehircilik ilkeleri ve planlama esaslarından uzak oluşu ve sağlıklı ve dengeli bir çevrenin oluşturulması gerekliliği karşısında söz konusu gecekondulaşmanın var olduğu alanların revize edilmesi ihtiyacı doğmuştur. Bu doğrultuda 775 sayılı Kanun çerçevesinde alansal bazda gecekondulaşmanın önlenmesi, tasfiyesi ve ıslahı için çeşitli hükümler öngörülmüştür. $\mathrm{Bu}$ çerçevede gecekondulaşma olgusunun önüne geçilmesi bakımından ıslahın mümkün olup olmadığ değerlendirilerek; bu mümkün değilse tasfiyenin yapılması icap etmektedir. 775 sayılı Kanun yürürlüğe girdikten sonra yapılacak gecekondular bakımından genel olarak yıkımın hedeflendiği görülse de getirilen imar affı kanunlarıyla bu hedeften sapılmıştır. 775 sayılı Kanun yürürlüğe girmeden önce yapılan gecekondular hakkında ise islah ve tasfiye bölgesi uygulaması kapsamında yıkım faaliyeti sonrasında arsa tahsisi söz konusu olabileceği gibi, belli şartların varlığı halinde yapının yerinde imar ve ıslahı, maliki tarafından gerçekleştirilebilir. Dolayısıyla 775 sayılı Kanun'un hem gecekondulaşma olgusunu kabullenen hem de bunun önüne geçmeye çalışan bir yapıda olduğu ve bunun da söz konusu alanların tespit edilerek 
sağlanmaya çalışıldığı ifade edilebilir. Ne var ki gerek bu alanların tespitinde gerekse arsa tahsis edilerek gecekondu önleme alanlarında, yeni konutların yapılması konusunda katılım ilkesine yeterince yer verilmemiştir. Bu durum ise, imar aflarının yanında bireylerin de süreçten bağımsız hareket etmesine, gecekonduların piyasa aracı haline gelmesine neden olmuştur. $\mathrm{O}$ halde, gecekondu islah bölgelerinde imar islah planlarının yapılması aşamasında ve önleme bölgelerinde sağlıklı yapılaşmanın sağlanmasına yönelik yapılan uygulamalarda katılım ilkesine riayet edilmesi gerekecektir. Zira kalıcı çözümlerin üretilebilmesi için planlama esasları ve şehircilik ilkelerinin yanında kamu yararının sağlamaya matuf hareket edilmesi ve yerel halkın bu süreçte etkin katılımının sağlanması gerekmekte olup; bu sayede yaşanabilecek hak kayıplarının önüne geçilebilecektir.

Hakem Değerlendirmesi: Çift kör hakem.

Finansal Destek: Yazar bu çalışma için finansal destek almadığını beyan etmiştir.

Çıkar Çatışması: Yazar çıkar çatışması bildirmemiştir.

Etik Kurul Onayı: Yazar, etik kurul onayının gerekmediğini belirtmiştir.

Peer Review: Double peer-reviewed.

Financial Support: The author declared that this study has received no financial support.

Conflict of Interest: The author has no conflict of interest to declare.

Ethics Committee Approval: The author stated that ethics committee approval is not required. 


\section{KAYNAKÇA}

Abdulhakimoğulları, Erdal ve Kale, Fatmagül. "Türk Anayasalarında ve Karşılaştırmalı Hukukta Konut Hakkı." Türkiye Adalet Akademisi Dergisi 4, no. 15 (2013): 15-38.

Akıllığlu, Tekin. "Yıkma Kararlarında Yöntem Sorunları." Amme İdaresi Dergisi 12, no. 4 (1979): 41-55.

Akkaya, Fethiye Nur. Kent Estetiğini Koruma Amaçlı İdari Kolluk Faaliyeti. İstanbul: On İki Levha Yayıncılık, 2016.

Aksoy, Abdulkadir. "Geleneksel Devletten Modern Devlete: Sanayi Devrimi ve Kamu Yönetimi Düşüncesinde Değişim." Uluslararası Politik Araştırmalar Dergisi 2, no. 3 (2016): 31-37.

Aksoy, Erman ve Güzey Kocataş, Özlem. “Gecekondu Alanlarında Uygulanan Kentsel Dönüşüm Projelerinin Meşruiyet Zemini Olarak Yoksulluk ve Suç." Karadeniz Teknik Üniversitesi Sosyal Bilimler Enstitüsü Sosyal Bilimler Dergisi 7, no. 14 (2017): 275-295.

Aksu Çam, Çiğdem ve Uygur, Ezgi. “Yıkım-Tapu-Dönüşüm Tartışmalarıyla Türkiye'de Enformel Konut Üretimi: Adana Örneği." Aksaray Üniversitesi İktisadi ve İdari Bilimler Fakültesi Dergisi 10, no. 4 (2018): 1-12.

Aktaş, Sevim. "The Urbanisation Issue and the Culture of Gecekondus in Turkey." Oriente Moderno 93 (2013): 176-187. Akyılmaz, Bahtiyar, Sezginer, Murat ve Kaya, Cemil. Türk İdari Yargılama Hukuku. Ankara: Savaş Yayınevi, 2018.

Alkışer, Yasemin ve Yürekli, Hülya. “Türkiye'de Devlet Konutunun Dünü, Bugünü, Yarını." İTü Dergisi/a 3, no. 1 (2004): 63-74.

Arseven, C. Esad. Şehircilik (Urbanizm). İstanbul: Devlet Basımevi, 1937.

Ayanoğlu, Taner. Yapı Hukukunun Genel Esasları. İstanbul: Vedat Kitapçılık, 2014. 
Aybay, Aydın. "A Survey of the Gecekondu Act, 1966, from the Standpoint of Effective Land Use." Annales de la Faculté de Droit d'Istanbul 23, no. 39 (1975): 203-207.

Azimli Çilingir, Gülcan ve Örçen Güler, İlke. "Afet Politikalarında Risk Unsuru ve Afet Mevzuatında Risk Yönetimi." Uluslararası Yönetim Akademisi Dergisi 3, no. 1 (2020): 152-165.

Bilgin, Hüseyin. “7153 ve 7181 Sayılı Kanunlarla İmar Kanununda Yapılan Değişiklikler Üzerine Bir İnceleme." Anadolu Üniversitesi Hukuk Fakültesi Dergisi 6, no. 2 (2020): 339-385.

Castells, Manuel. Kent Sınıf Iktidar. Çev. Asuman Türkün. Ankara: Phoenix Yayınları, 2014.

Ceritli, İsmail. "Kentsel Planlamanin İlkeleri ve Türkiye'de Gecekondu Sorunu." Öneri Dergisi 2, no. 10 (1998): 49-57.

Cihangir Çamur, Kübra. "İmar Islah Planlarının Ankara Kent Makroformu Üzerindeki Yoğunluk Etkileri." Planlama Dergisi, no. 1-4 (1996): 15-19.

Çakır, Sabri. “Türkiye'de Göç, Kentleşme/Gecekondu Sorunu ve Üretilen Politikalar." Süleyman Demirel Üniversitesi Fen Edebiyat Fakültesi Sosyal Bilimler Dergisi, no. 23 (2011): 209222.

Çaptuğ, Mehpare. İdare Hukuku Açısından Kentsel Dönüşüm. Ankara: Seçkin Yayıncılık, 2016.

Çelik, Abdullah. "Kent Yönetimi Bağlamında Kent Konseyinin İşlevleri Üzerine Bir Değerlendirme." Cumhuriyet Üniversitesi İktisadi ve İdari Bilimler Dergisi 14, no. 2 (2013): 215-229.

Derdiman, R. Cengiz. "Kentleşmenin Suça Etkisi ve Kentlilerin Suçla Mücadelesinin Sosyal ve Hukuki Boyutları." Çağdaş Yerel Yönetimler Dergisi 19, no. 3 (2010): 49-73. 
Dural, A. Baran ve Zeyrekli, Sedef. "Göç Sorunu ve Gecekondulu Nüfusun İktidara Yürüyüşü." Çă̆daş Yerel Yönetimler Dergisi 15, no. 4 (2006): 5-15.

Eke, Feral. “Gecekondu Alanlarının Değerlendirilmesine İlişkin Çözümler." Süleyman Demirel Üniversitesi İktisadi ve İdari Bilimler Fakültesi Dergisi 5, no. 1 (2000): 43-54.

Eraslan, Yunus ve Boz, S. Sacit. "İdari Yargılama Usulünde İncelenmeksizin Ret Kararları." Türk İdare Dergisi 91, no. 488 (2019): 203-243.

Erdoğan, M. Murat ve Ömürgönülşen, Murat. "Yeminli Özel Teknik Bürolar: Gecekondu Sorunu, İmar Affı ve Kamu Hizmetlerinin Özel Kişilere Gördürülmesi Açısından Bir Değerlendirme." Hacettepe Üniversitesi İktisadi ve İdari Bilimler Fakültesi Dergisi 7, no. 1-2 (1989): 173-214.

Erkelli Kızıl, Neşe. “2981 Sayılı İmar Affı Kanunu ve Bu Kanuna Dayanılarak Kurulan Yeminli Özel Teknik Büroların Faaliyet Süreci." İdare Hukuku ve İlimleri Dergisi 4, no. 1-3 (1983): 73-81.

Erman, Tahire. "Formalization by the State, Re-Informalization by the People: A Gecekondu Transformation Housing Estate as Site of Multiple Discrepancies." International Journal of Urban and Regional Research 40, no. 2 (2016): 425-440.

Eroğlu, Şebnem. "Extending the Resource-Based Approach to Livelihoods: An Urban Application to Turkish Gecekondu Households." International Journal of Urban and Regional Research 37, no. 2 (2013): 769-789.

Ersöz, A. Kürşat. "Bir İdari İşlem Olarak Yıkım Kararı." Gazi Üniversitesi Hukuk Fakültesi Dergisi 19, no. 3 (2015): 103-149.

Genç, Fatma N. “Türkiye'de Kentsel Dönüşüm: Mevzuat ve Uygulamaların Genel Görünümü." Yönetim ve Ekonomi Dergisi 15, no. 1 (2008): 115-130.

Genç, Mustafa. İmar Hukuku. Ankara: Seçkin Yayıncılık, 2015. 
Geray, Cevat. "Gecekondu Sorununa Toplu Bir Bakış." Amme İdaresi Dergisi 1, no. 2 (1968): 11-29.

Geray, Cevat. “Mesken Meselesi ve Dördüncü İskân ve Şehircilik Haftası." Ankara Üniversitesi Siyasal Bilgiler Fakültesi Dergisi 15, no. 3 (1960): 123-128.

Geray, Cevat. "Urbanization in Turkey." Ankara Üniversitesi Siyasal Bilgiler Fakültesi Dergisi 24, no. 4 (1969): 157-174.

Giritlioğlu, Cengiz. "İç Göç ve Kentlileşme." Türkiye'de Kentleşme, Ankara: Yeni Yüzyıl Kitaplığı, (1995): 30-56.

Giritlioğlu, P. Pınar ve Özden, Kardelen. "Kentsel Adalet Ekseninde İmar Afları: İmar Barışı Üzerine Bir Değerlendirme." Prof. Dr. Necla Giritlioğlu'na Armă̆an, İstanbul: On İki Levha Yayıncılık, 2020, 255-283.

Gönüllü, Günay. “Çevresel-Kentsel Hakların Gelişimi: Dünyada ve Türkiye'de Kentsel Haklar." Insan Hakları Yıllı̆̆ı Dergisi 32 (2014): 31-52.

Gözler, Kemal. Türk Anayasa Hukuku. Bursa: Ekin Yayınevi, 2018.

Gülan, Aydın. "Şehircilik Sorunlarının Ağırlaşmasında Hukukun Rolü Hakkında Düşünceler." İstanbul Üniversitesi Sosyoloji Dergisi 3, no. 22 (2011): 295-303.

Güler, Tuğba ve Coşgun, Nilay. "Yapı Üretim Sürecinde Belediyelerin Rolü." Çă̆daş Yerel Yönetimler Dergisi 20, no. 2 (2011): 53-71.

Gündüz, Altay. "Gerçek Yapısal Riskin Tahmin Edilmesi Üzerine." Türkiye İnşaat Mühendisliği 13. Teknik Kongresi Bildiriler Kitabl, Ankara: 1995, 281-294.

Güzey, Özlem. “The Last Round in Restructuring the City: Urban Regeneration becomes a State Policy of Disaster Prevention in Turkey." Cities 50 (2016): 40-53.

Heper, Metin. “Türkiye'de Gecekondu Politikası Üzerine Bazı Düşünceler." Amme İdaresi Dergisi 12, no. 4 (1979): 55-62. 
İnce, Nurten, Kanlı, İ. Bakır ve Eryiğit, B. Hamza. "İnsan Hakk1 Olarak Konut Hakkı." Uluslararası Politik Araştırmalar Dergisi 3, no. 2 (2017): 21-36.

Kalabalık, Halil. İmar Barışı Başvuru Süreci ve Sonuçları. Ankara: Seçkin Yayıncılık, 2018.

Kalabalık, Halil. İmar Hukuku Dersleri. Ankara: Seçkin Yayıncılık, 2019.

Kaman, Nur. "Mahalli İdarelerin Yetkilerinin ve Sınırlarının Kaynağı Olarak Mahalli Müşterek İhtiyaç." İstanbul Medipol Üniversitesi Hukuk Fakültesi Dergisi 7, no. 1 (2020): 73-87.

Kaplan, Onur. İdare Hukuku Yönünden Afet Riski Altındaki Alanların Kentsel Dönüşüm Süreci. İstanbul: On İki Levha Yayıncılık, 2017.

Kara, Mustafa. “Türkiye' de Gecekondu Dönüşüm Projelerinin Konut Sorununun Çözümündeki Rolü: Ankara İli Gültepe ve Yatıkmusluk Örneği." Girişimcilik ve Kalkınma Dergisi 5, no. 2 (2010): 171-204.

Karahanoğulları, Onur. İdarenin Hukukla Kavranması: Yasallık ve İdari İşlemler. Ankara: Turhan Kitabevi, 2018.

Kaya, Mustafa. "Gecekondu Sorunu ve Gecekondu Kanunu." Türkiye Barolar Birliği Dergisi, no.1989/6 (1989): 860-891.

Keleş, Ruşen. "Türkiye'de Şehirleşme Hareketleri." Ankara Üniversitesi Siyasal Bilgiler Fakültesi Dergisi 25, no. 4 (1970): 41-83.

Keleş, Ruşen. 100 Soruda Türkiye'de Kentleşme, Konut ve Gecekondu. İstanbul: Cem Yayınevi, 2015.

Keleş, Ruşen. Kentbilim İlkeleri. Ankara: Sevinç Matbaası, 1976.

Keleş, Ruşen. Kentbilim Terimleri Sözlüğü. Ankara: İmge Kitabevi, 1998.

Kılıçbay, M. Ali. Şehirler ve Kentler. Ankara: Gece Yayınları, 1993. 
Köktürk, Erdal. “Türkiye' de Gecekondu ve İmar Affı Üzerine Bir İnceleme." Jeodezi, Jeoinformasyon ve Arazi Yönetimi Dergisi, no. 2003/89 (2003): 49-66.

Köroğlu, Ömer. İmar Hukukunda Yapı Kavramı ve Temel Yapı Belgeleri. İstanbul: On İki Levha Yayıncılık, 2017.

Labort, Henri. İnsan ve Kent. Çev. Bertan Onaran. İstanbul: Payel Yayınları, 1990.

Mangın, William. "Latin American Squatter Settlements: A Problem and a Solution." Latin American Research Review 2, no. 3 (1967): 65-98.

Oder, Burak. "Regülasyon Kavramı Üzerine Bir Deneme." Prof. Dr. A. Ülkü Azrak 75. Yaş Armă̆anı, İstanbul: Çizgi Basım Yayın, (2008): 239-254.

Okay Tekinsoy, Özge. İdare Hukukunda Kamu Düzeni Kavramı. İstanbul: On İki Levha Yayıncılık, 2011.

Onar, S. Sami. İdare Hukukunun Umumî Esasları Cilt-I. İstanbul: Hak Kitabevi, 1966.

Öngören, Gürsel. “Kentsel Dönüşüm İmar Planlamasında Yetki." Legal Hukuk Dergisi 11, no. 123 (2013): 3-34.

Örücü, Esin. "A Synthetic and Hyphenated Legal System: The Turkish Experience." Journal of Comparative Law 1, no. 2 (2006): 27-47.

Örücü, Esin. Sosyal Refah Devletinde Bir Sosyal Kamu Hizmeti Konut. İstanbul: İstanbul Üniversitesi Hukuk Fakültesi Yayınları, 1972.

Özay, İl Han. Günışığında Yönetim. İstanbul: Filiz Kitabevi, 2004.

Özden, P. Pınar. Kentsel Yenileme Yasal Yönetsel Boyut Planlama ve Uygulama. Ankara: İmge Kitabevi, 2016.

Özden, P. Pınar ve Kubat, A. Sema. "Türkiye'de Şehir Yenilemenin Uygulanabilirliği Üzerine Düşünceler." İTÜ Dergisi/a 2, no. 1 (2003): 77-88. 
Sağlam, Serdar. "1923-1950 Yılları Arasında Türkiye'de Kent ve Kentleşme Olgusu." Sosyoloji Konferanslar 53 (2016): 257274.

Sancakdar, Oğuz. Belediyenin İmar Planını Yapmas1Değiştirmesi ve İptal Davası. Ankara: Yetkin Yayıncılık, 1996.

Şahin, Cenk. Acele Kamulaştırma. İstanbul: On İki Levha Yayıncilık, 2018.

Tatlıdil, Ercan. Kentleşme ve Gecekondu. İzmir: Ege Üniversitesi Edebiyat Fakültesi Yayınları, 1989.

Tekeli, İlhan. Kent, Kentli Hakları, Kentleşme ve Kentsel Dönüşüm. İstanbul: Tarih Vakfı Yurt Yayınları, 2011.

Tercan, Binali. “Günümüze Değin İmar Afları.” Planlama Dergisi, no. 1-4 (1996): 5-8.

Toksöz, Fikret. "Yerel Yönetim ve Kentsel Ekonomik Sektöre Müdahale." Mimarlik Dergisi 15, no. 2 (1977): 51-52.

Tuna, Orhan. “Türkiye'de Gecekondu Önleme Bölgeleri Hakkında Bir Araştırma ve Yeni Bir Model Taslağı." Sosyal Siyaset Konferanslarl, İstanbul: Bilmen Basımevi, (1977): 1-13. Türkoğlu, Kamutay ve Atik, A. Saffet. “Bütünsel Kentsel Planlama ve Altyapı Projelendirmesi Kent Yönetiminin ve Kentsel Gelişmenin Ayrılamaz İkilisidir." I. Ulusal Kentsel Altyapı Sempozyumu Bildiriler Kitabı, G. Antep: TMMOB İnşaat Mühendisleri Odası Yayınları, (1997): 1-8.

Türkün, Asuman, Aslan, Şükrü ve Şen, Besime. “1923-1980 Döneminde Kentsel Politikalar ve İstanbul'da SosyoMekânsal Dönüşüm." Mülk, Mahal, İnsan İstanbul'da Kentsel Dönüşüm. Der. Asuman Türkün. İstanbul: İstanbul Bilgi Üniversitesi Yayınları, (2014): 45-78.

Utkucu, Tamer ve Çağlan, Elif. Rant İmar İtibar. İstanbul: On İki Levha Yayıncilık, 2019.

Ünal, Yücel. Türk Şehir Planlama Hukukunun Bugünü (1985-2015). İstanbul: Legal Yayıncılık, 2015. 
Üstün, Gül. Kentsel Dönüşüm Hukuku. İstanbul: On İki Levha Yayıncılık, 2014.

Yasin, Melikşah. "Kentsel Dönüşüm Uygulamalarının Hukuki Boyutu." Türkiye Barolar Birliği Dergisi, no. 60 (2005): 105-137.

Yasin, Melikşah. İmar Hukukunda İdarenin Yıkma Yetkisinin Kullanımının Usul ve Esasları. İstanbul: On İki Levha Yayıncilık, 2009.

Yavuz, Fehmi, Keleş, Ruşen ve Geray, Cevat. Şehircilik SorunlarUygulama ve Politika. Ankara: Sevinç Matbaası, 1973.

Yayla, Yıldızhan. Şehir Planlamasının Başlıca Hukukî Meseleleri ve İstanbul Örneği. İstanbul: İstanbul Üniversitesi Hukuk Fakültesi Yayınları, 1975.

Yllmaz, Nurcan. "Portakal Çiçeği Vadisi ve Dikmen Vadisi Kentsel Dönüşüm Projeleri." Kentsel Dönüşüm Hukuku. Der. Melikşah Yasin ve Cenk Şahin. İstanbul: On İki Levha Yayıncılık, (2015): 441-482.

\section{Online Kaynaklar}

(https://legalbank.net)

(http://www.kazanci.com)

(https://www.mevzuat.gov.tr)

(https://www.uyusmazlik.gov.tr)

(https://www.resmigazete.gov.tr)

(https://www.lexpera.com.tr) 